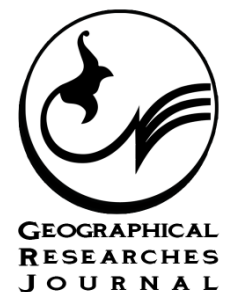

\title{
Drought Status and its Management from the Viewpoint of Professionals and Households' Heads in Rural Areas of Eslamabad Gharb, Iran
}

\section{ART I C L E I N F O}

\section{Article Type}

Original Research

\section{Authors}

Shafeie B. ${ }^{1} M A$

Barghi H. ${ }^{* 1} P h D$,

Ghanbari Y. ${ }^{1} P h D$

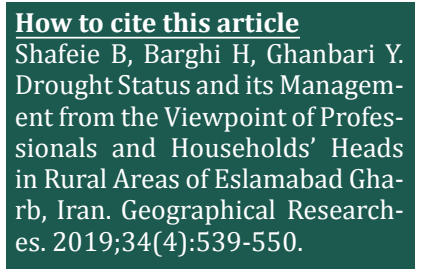

${ }^{1}$ Department of Geography and Rural Planning, Faculty of Geographical Sciences and Planning, University of Isfahan, Isfahan, Iran

\section{*Correspondence}

Address: Faculty of Geography and Planning, Isfahan University, Azadi Square, Isfahan, Iran Phone: +98 (31) 7933150 Fax: +98 (31) 7935773 h.barghi@geo.ui.ac.ir

\section{Article History}

Received: June 7, 2019

Accepted: October 29, 2019

ePublished: December 11, 2019

\section{A B S T R A C T}

Aims \& Backgrounds Climate change, the quantitative and qualitative decline of water resources and the increasing trend of the world's population have made water management difficult. The purpose of this study was to assess the situation and management of meteorological and agricultural droughts from the point of view of experts and household supervisors in rural areas of Eslamabad Gharb.

Methodology This descriptive-analytical study was conducted in 2017 in 7 households of Eslamabad Gharb. A total of 374 households (in 21 villages) were selected through multi-stage stratified random sampling. Data were collected through library and field research (questionnaire and interview). To analyze the quantitative data, standardized precipitation indices, standardized transpiration and onesample T-test, and in the qualitative part, Delphi method was used..

Findings According to the results of the Standardized Precipitation Index, from 1986 to 2016, 14 years of drought occurred at the county level ( 8 years normal, 4 years moderate and 2 years severe). According to the results of the long-term standardized transpiration index, $2.1 \%$ of the city population was affected by moderate drought in $2008-2009$, and $64.6 \%$ by mild drought.

Conclusion Rural participation in drought management planning is the most important and effective factor affecting drought management.

Keywords Drought Management; Rural Areas; Spi Index; Spei; Delphi; Eslamabad Gharb

\section{I T A T I O N L I N KS}

[Alavizadeh \& Izadi; 2018] Analysis of the effects of drought on the ...; [Agricultural Jihad Organization of Kermanshah Province; 2014] Statistics of horticultural and ...; [Alipour, et al; 2013] The effects of drought on farmers' economic and social ...; [Amir Khani, et al; 22012] Effective factors in farmers management type ...; [Atlas of the districts of Kermanshah province; 2017] The country's planning and budget organization, the ...; [Campbell, et al; 2016] Dealing with drought: Small farmers and environmental ...; [Dehban, et al; 2015] Presentation and evaluation of the new index of MRDI in ...; [Dehghanpour, et al; 2017] Drought risk management a step towards sustainable ...; [Dehghani; 2014] Analysis of the effects of drought on ...; [Elfaigh; 2015] Strategies to reduce drought vulnerability with special emphasis on coping ...; [Esmaeili \& Khodadad; 2017] Drought risk management, and its effects on the economic recovery of ...; [Fard Moradinia \& Soleimanzadeh; 2016] Drought management, the most important part of water ...; [Faryabi \& Mozafarizadeh; 2017] Hydrological drought management index ...; [Folkman; 2018] Personal control and coping processes: A theoretical ...; [Ghasemi Azad Khani; 2014] Drought status assessment in...; [Gholami \& Ali Beigi; 2014] Identification of native methods of drought ...; [Governorate of Eslamabad Gharb; 2005] Strategic development plan of Eslamabad ...; [Hafeznia; 2005] Introduction to the research method ...; [Hasani Nejad, et al; 2018] The role of drought risk management in ...; [Iran's Statistics Center; 2017] Detailed results of population and housing ...; [Jamshidi, et al; 2015] The effects of drought on the economy of ...; [Keshavarz \& Karami; 2008] Effective structures on ...; [Kiani Selmi \& Amini Faskhoodi; 2017] Explaining the social factors of drought and ...; [Maleki \& Torkmani; 2015] Drought management for optimal use of ...;[Maponya \& Mpandeli; 2012] Climate change and agricultural production ...; [Mohammadi Yeganeh , et al; 2012] Drought effects on the...; [Naveen, et al; 2014] Vulnerability and policy relevance ...; [Rezaei, et al; 2016] Analysis of farmers' status, east of Zayandehrood ...; [Riahi \& Pasha Zadeh; 2013] The economic and social effects ...; [Salman Shahraki; 2015] Drought management survey among ...;[Sadeghloo, et al; 2017] Measuring the level of knowledge and ...; [Shams, et al; 2011] Effective factor analysis, on optimal ...; [Sharafi \& Zarafshani; 2011] Vulnerability assessment, risk ...; [Sobhani \& Goldust; 2015] Drought monitoring, and its possibility ... ; [Soleimani, et al; 2018] The effect of drought on groundwater, ...; [Mahmoudi \& Seyyed; 2003] The role of information systems in ...;[Mohammad, et al; 2010] Disaster management and ...; [Vento, et al; 2010] Coping with drought in irrigated ...; [Tarmeh, Consulting Engineers; 2006] Structural analysis structure ...; [Yazdani \& HaghSheno; 2007] Drought management and diversion ...; [Yousefi, et al; 2015] Drought management and zonation ...; 
Q بهمن شفيعى و همكاران QF。

بهعنوان يك يديده طبيعى موجب برهمزدن هرجه بيشتر توازن بين

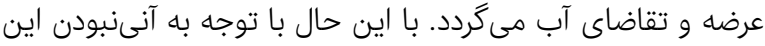

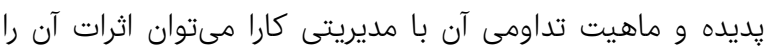

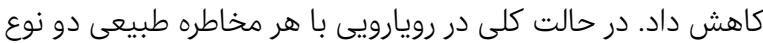

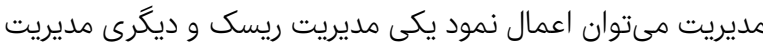
بحران[Fard Moradi Nia \& Soleimanzadeh, 2016] مديريت ريسك بايستى قبل از مديريت بحران به معنى عام خود

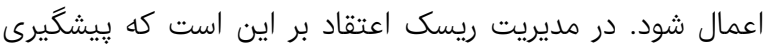

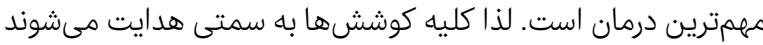
كه هرگز بحرانى اتفاق نيفتد [Mahmoudi, 2003] كشورهاى در حال توسعه دنبال مىكنند مديريت بحران الفيف است.

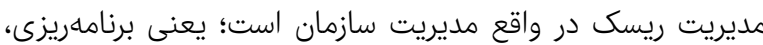
هدايت و كنترل سيستمهاى سازمان و منابع جهت وصول به اهداف [MohammadNia Qarai et al, 2010] بـ بديده خشكسالى آثار منفى بزرگى بر منابع آب و محيطهاى وابسته به آن مى خذارد و در

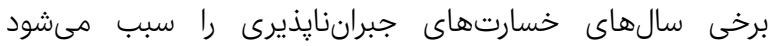
[Faryabi \& Mozafarizadeh, 2017]. خشكسالى بهعنوان بلاى طبيعى و يديدهاى اجتناب نايذير، از ديرباز در يهنها وسيع كشورهاى مختلف به خصوص كشورهاى مستقر در مناطق گرم و خشك به كرات وقوع يافته و مىيابد. لذا اين يديده زيانهاى جيان جبران

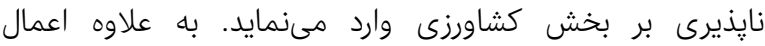

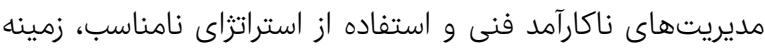
را براى بروز خشكسالىهاى بعدى به طرز فزاينداى فراى فراهم مينمايد

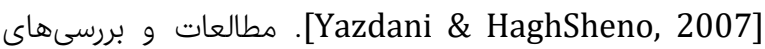
انجامشده نشانكر آن است كه كشور ايران با توجه به وضعيت

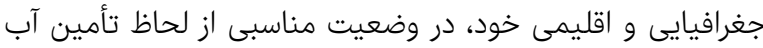

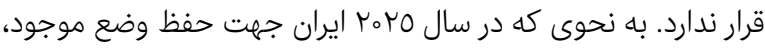

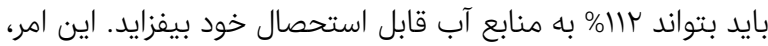
بيانكر احتمال وقوع خشكسالىهاى بيشترى در آينده نسبت بـابل بهابل

كذشته است. [Keshavaerz \& Karami, 2008] خشكسالى خسارات زيادى را به جوامع انسانى به خصوص نوالى نواحى

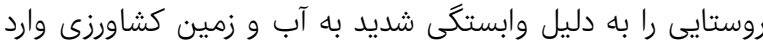
كرده است كه اين امر در مناطقى كه عمده فعاليت آنها كشاورزى و و

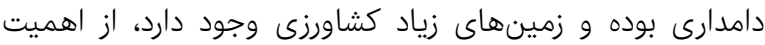

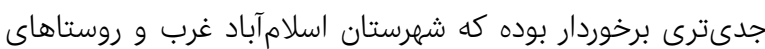
دربردارنده آن در زمره اين موارد است.

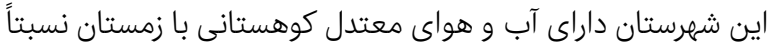

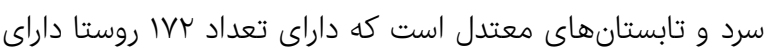

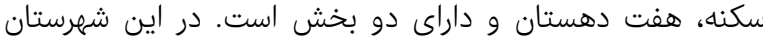
منبع درآمد اغلب روستاها وابسته به كشاورزى و دامدارى است داريت كه داري در سالهاى اخير بروز و وجود خشكسالىهاى متعدد، منبع درآمدى آنى

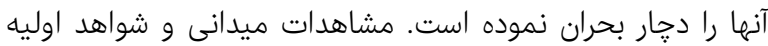
نشان مىدهد كه خشكسالى موجب رخدادهاى مانى مانند افزايش مهاجرت روستاييان به شهرها، كاهش سطح زيركشت، تغيير كاربرى مالى
وضعيت خشكسالى و مديريت آن آن آن ديدگاه كارشناسان وسريرستان خانوارها در نواحى روستايى اسلام آباد غرب

بهمن شفيعى MA كروه جغرافيا و برنامهريزى روستايى، دانشكده علوم جغرافيا و برنامهريزى، دانشخاه اصفهان، اصفهان، ايران

PhD حميد برقى PhD كَروه جغرافيا و برنامهريزى روستايى، دانشكده علوم جغرافيا و برنامهريزى، دانشكاه اصفهان، اصفهان، ايران

يوسف قنبرى PhD كروه جغرافيا و برنامهريزى روستايى، دانشكده علوم جغرافيا و برنامهريزى،

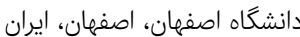

جكيده اهداف و زمينهها: تغييرات اقليم، كاهش كمّى و كيفى منابع آب و روند افزايشى آبى جمعيت جهان مديريت منابع آب را با مشكل روبهرو كرده است. هدف البن اين يزوهش، بررسى وضعيت و مديريت خشكسالىهاى هواشناسى و زراعى از ديدكاه

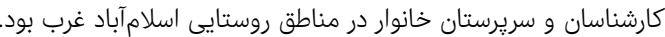

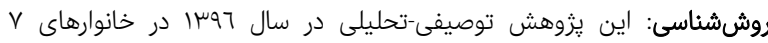

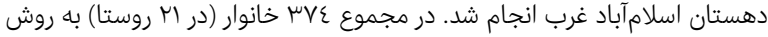

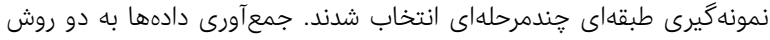

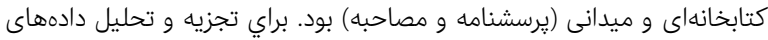

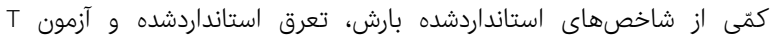

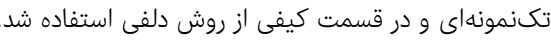

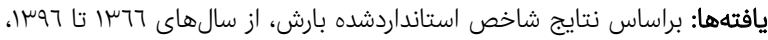

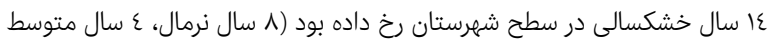

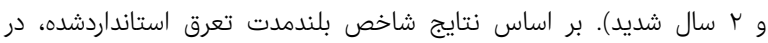

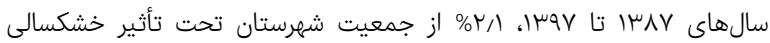

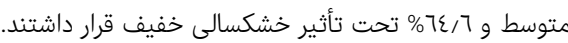

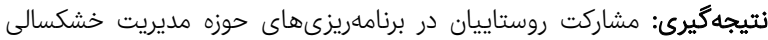

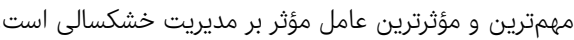

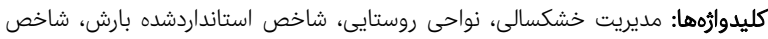

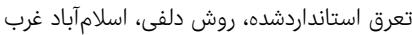

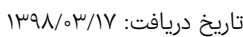

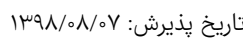
"نويسنده مسئول: h.barghi@geo.ui.ac.ir

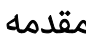

تغييرات اقليم و كاهش كمى و كيفى منابع آب قابل استفاده از

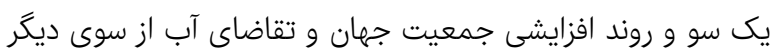

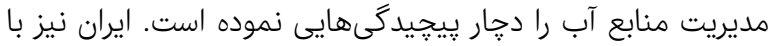

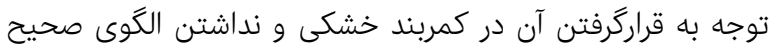

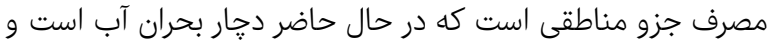

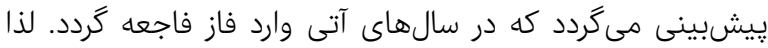

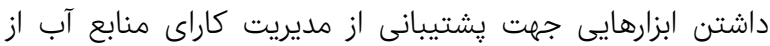
ضروريات مديريت آب كشور خواهد بود. در اين بين خشكسالى آنى 


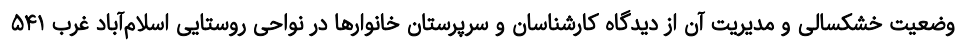

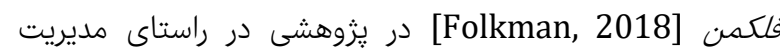

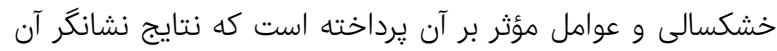

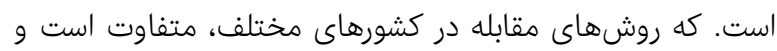

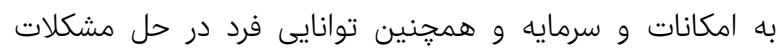

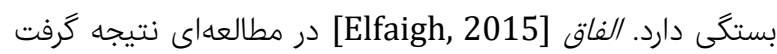

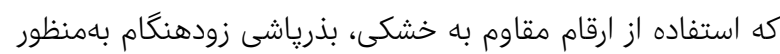

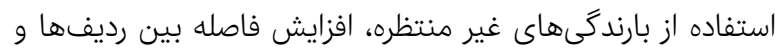

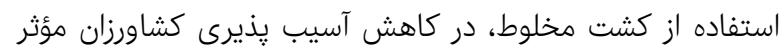

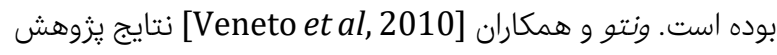
آنها نشان داد كه كشاورزان از تعديلخرهاى مديريتى مانند

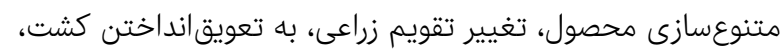

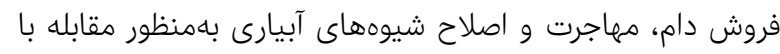

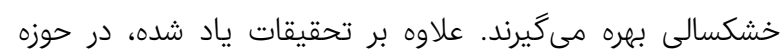

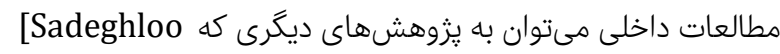
et al, 2017; Maleki et al, 2015; Dehghanpoor et al, 2017; Dehghani et al, 2014; Alavizadeh \& Izadi, 2018; Gholami \& Ali Beigi, 2014; AliPour et al, 2013; 2012] Mohammadi Yeganeh,

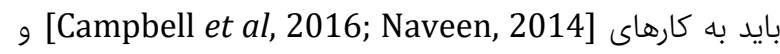
درباره مديريت خشكسالى انجام دادهاند، اشاره كرد. با توجه به به به

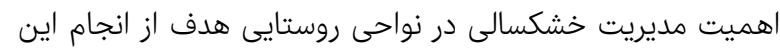

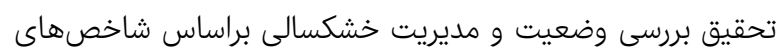
SPEI SPI غرب است. نوآورى اين يزوهش را مىتوان از دو جنبه نظرى و كاربردى مورد

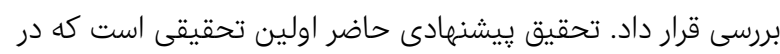

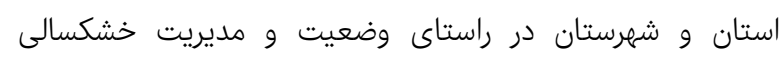

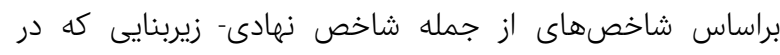
تحقيقات قبلى ذكر نشده در نواحى روستايى انجام مى اخیابد.

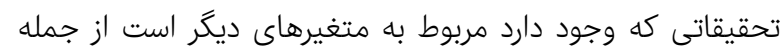

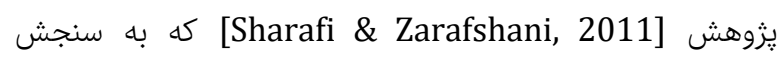
آسيبذيذيرى، نقطه آغاز مديريت ريسك در خشكسالى مطالعه

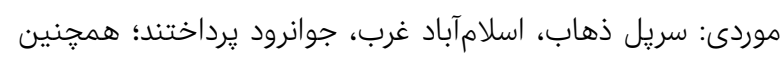

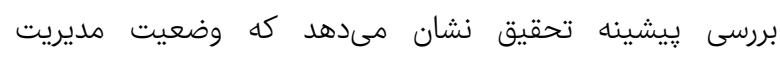
خشكسالى در مناطق مختلف با توجه به شرايط مختلف اقتصادى،

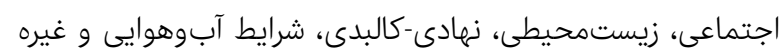

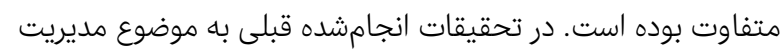

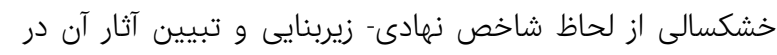

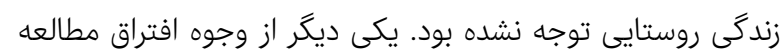

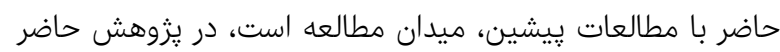

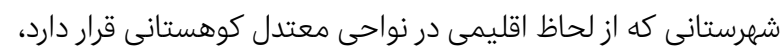

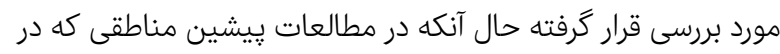

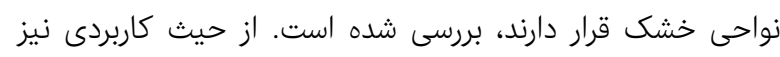

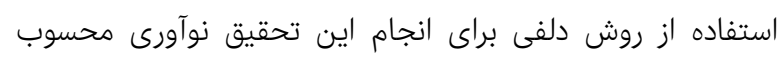

اراضى از كشاورزى به غير كشاورزى، فروش اراضى زراعى، فروش

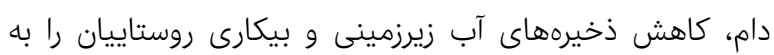

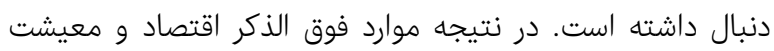

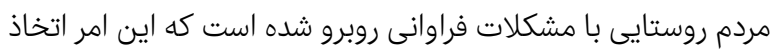
رويكرد جامع را در مديريت و يايش خشكسالىها و ارزيابى و تبيين مرداني

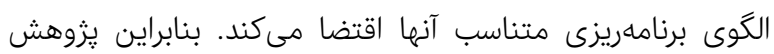
حاضر در بى پاسخ به سئوالات زير است.

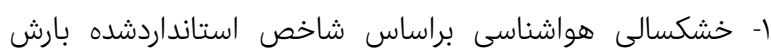

(SPI)

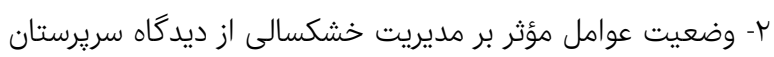

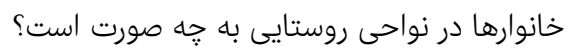
س- جه عواملى بر مديريت خشكسالى از ديدگًاه كارشناسان در نواحى روسى روستايى مؤثر است؟ مونى بر مديريت يزوهشهاى متعددى در زمينه بررسى وضعيت و و مديت مديريت

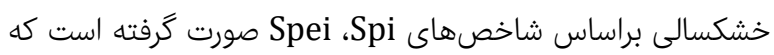

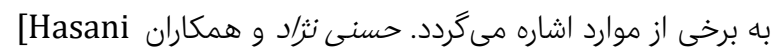

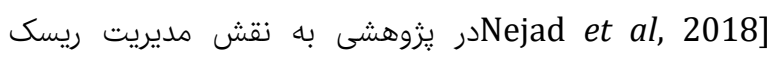

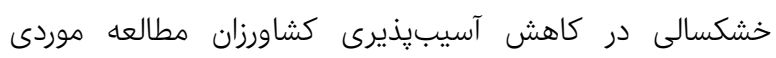

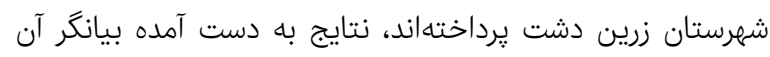

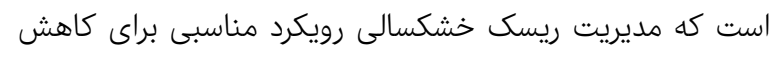

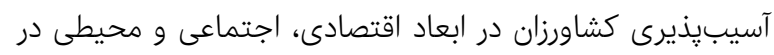
مناطق روستايى است.

[Kiani Salmi \& Amini كيانى سلمى و فنسخودى ) [ در يزوهشى با عنوان تبيين عوامل اجتماعى

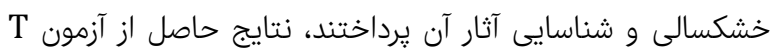

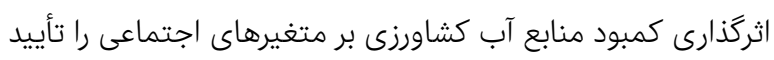

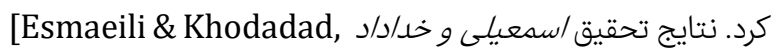

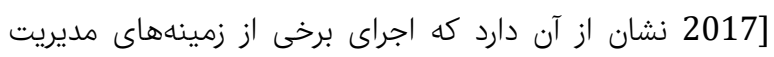

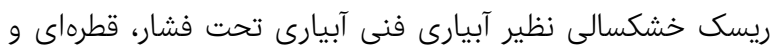

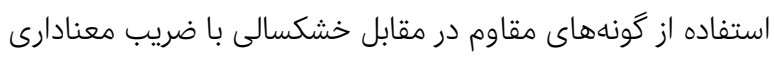

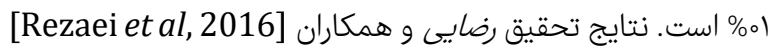
كه از شاخص نمايه استاندارد بارش (SPI) و تحليل هزينه فايده

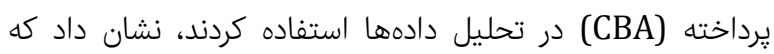

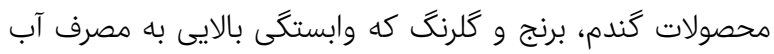

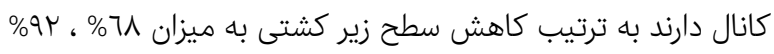

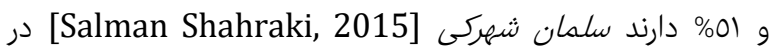
يزوهشى كه به بررسى مديريت خشكسالى در بين كشاورزان از منظر

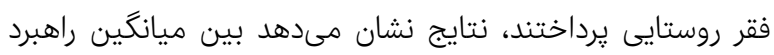

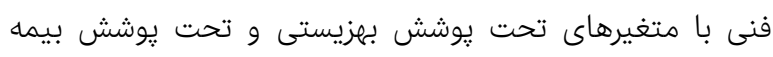

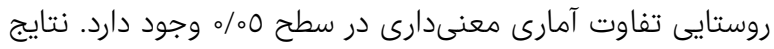
تحقيق سبحانى و كل دوست [Sobhani \& Goldust, 2015 نشان داد كه شديدترين خشكسالى در استان اردبيل در ايستخاه

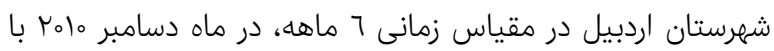

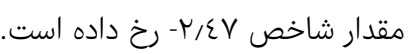


تعرق استانداردشده Spei همجنين در قسمت كيفى با استفاده از روش دلفى (Delphi) از مro نفر از متخصصان و كارشناسان و افراد دماد

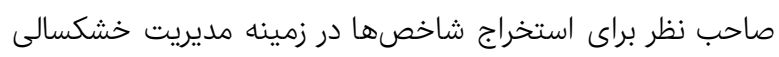
در نواحى روستايى استفاده شده است.

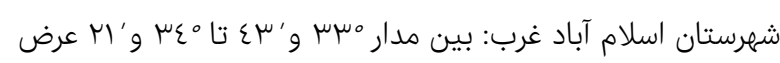
شمالى و

كرينويج واقع شده است [Iran's Statistics Center, 2016]. اين شهرستان در ناحيه كوهستانى واقع شده است و داراى آب و و

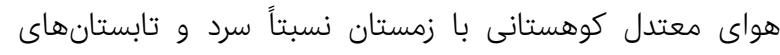

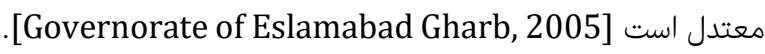
فاصله شهرستان مذكور تا مركز استان ه7 كيلومتر و همجنين ارتفاع

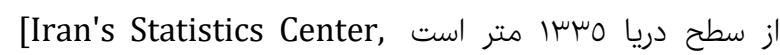
[Atlas of rural districts of kermanshah 2016]

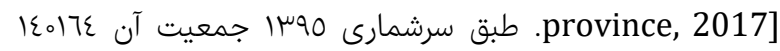

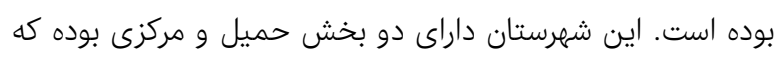

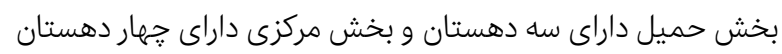

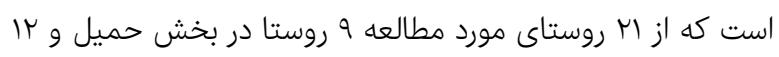

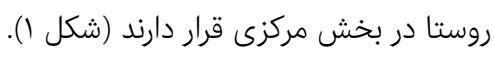

\section{روش}

روش يزوهش از لحاظ هدف در زمره تحقيقات كاربردى و از نظر

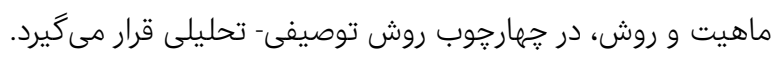

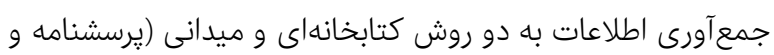
مصاحبه) بوده است. جامعه آمارى مورد مطالعه را كل خانوارهاى

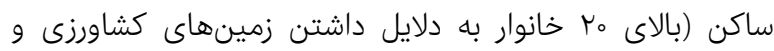

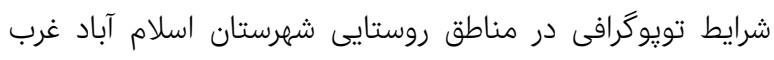
(هفت دهستان) كه طى سالهاى خشكسالى قرارگرفتهاند، تشكيل مى نىهند. كه به براساس سرشمارى

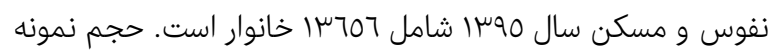

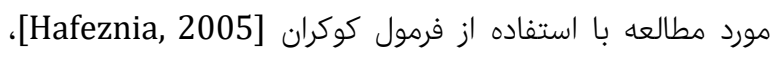

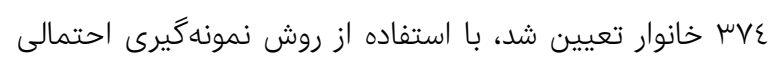

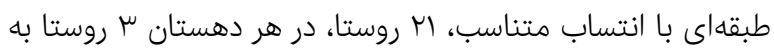
دليل ساختار محيطى بهعنوان روستاهاى هدف در نظر گرفته و در

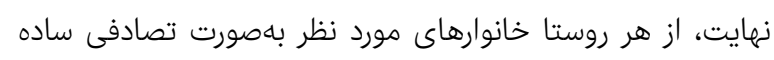

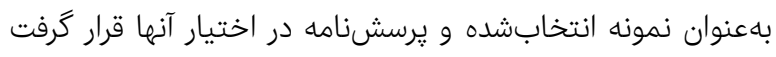

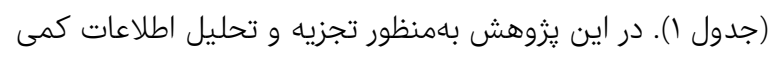

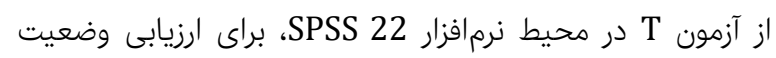

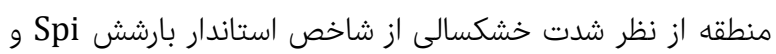

جدول () معرفى نمونه آمارى تحقيق بر حسب شهرستان اسلام آباد غرب

\begin{tabular}{|c|c|c|c|c|c|}
\hline درصد حجم نمونه & نمونه انتخابى & خانوار & ساختار محيطى & روستا & دهستان \\
\hline$k$ & If & IEF & كوهستانى & جشمه سنكى & \\
\hline 1 & k & $\mu F$ & كوهستانى & ميان تنگ منصورى & منصورى \\
\hline r & $\wedge$ & 101 & كوهستانى & مومنايى & \\
\hline 10 & w & 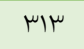 & كوهستانى & كندهر & \\
\hline r & 9 & VQ & جنكًل واقع در تيه & 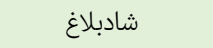 & هرسم \\
\hline r & $\wedge$ & 49 & دشتى & مله هار & \\
\hline$\Delta$ & 11 & $19 \%$ & كوهستانى & يلنغ گرد & \\
\hline 0 & $r_{0}$ & Mr & د دشتى & كردنكاه قوجمى & حميل \\
\hline 1 & Q & mq & دشتى & توه سرخك عليا & \\
\hline v & ru & rVG & دشتى & حسن آباد & \\
\hline 0 & IV & $19 \%$ & كوهستانى & تنگ شوهان عليا & حسن آباد \\
\hline 7 & r & rir & كوهستانى & انجيرى & \\
\hline 11 & \&4 & 499 & دشتى & جقاكبود & \\
\hline 9 & rr & iAv & دشتى & ونايى & حومه جنوبى \\
\hline 1 & k & M & دشتى & ميلكَه سياه سياه & \\
\hline 7 & $r r$ & $r \mu k$ & دشتى & جقازرد جويانكاره & \\
\hline 1 & $k$ & Q. & دشتى & جفته & حومه شمالى \\
\hline$\mu$ & 10 & 118 & جنكل واقع در تيه & سرخك & \\
\hline$\wedge$ & $\mu$ & $\Delta \wedge \varsigma$ & كوهستانى & قلعه شيان & \\
\hline 1 & $k$ & $g k$ & دشتى & معارفى & شيان \\
\hline$\mu$ & ir & $r m a$ & كوهستانى & ميرغزيزى & \\
\hline
\end{tabular}




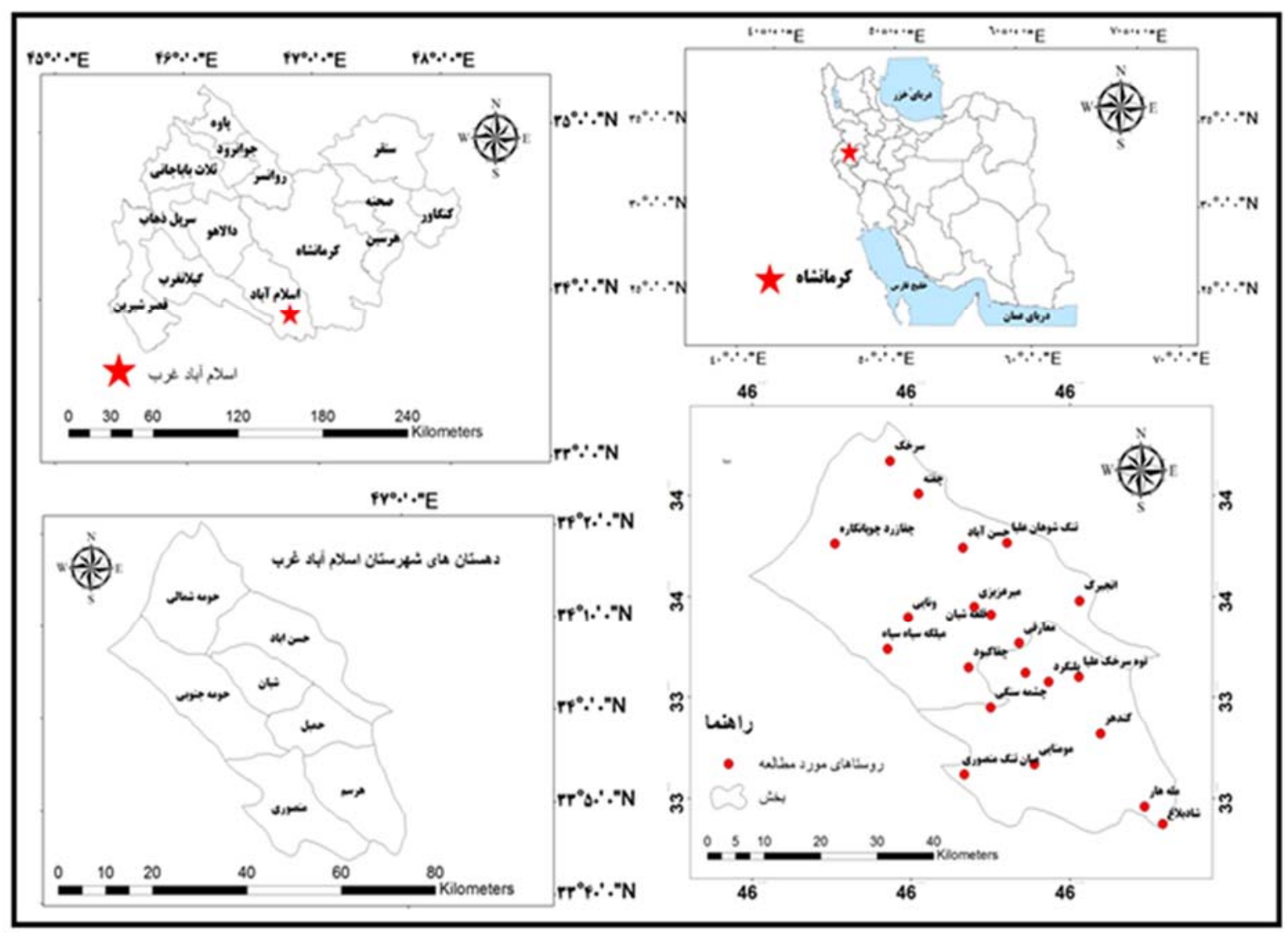

شكل () موقعيت منطقه مطالعه شده و روستاهاى نمونه در كشور، استان و شهرستان

يايينتر از متوسط نرمال توليد (1000 كيلوگرم در هر هكتار) است.

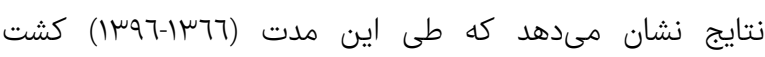

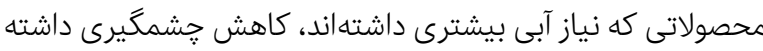

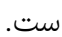
شهرستان اسلامآباد غرب داراى دو شهر به نامهاى اسلامآباد غرب و

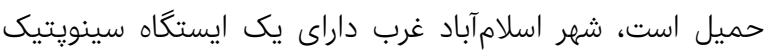

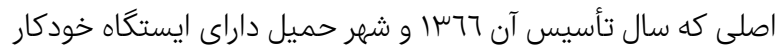

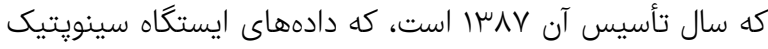
اصلى بهصورت مرتب ثبتشده و موجود است، فاصله زمانى تأسيس

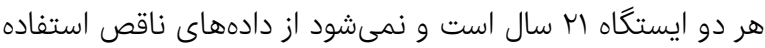

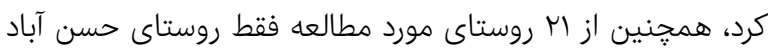

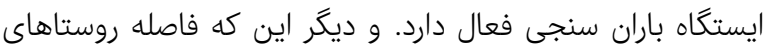

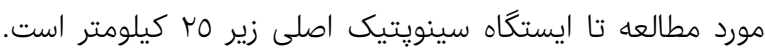
بنابراين براى بررسى وضعيت و مديريت خشكسالى براساس نظر

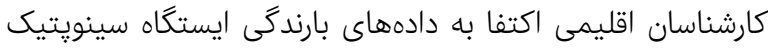

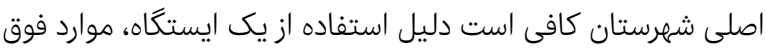

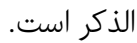
بهمنظور محاسبه شاخص استاندارد بارش از معادله زير استفاده شد:

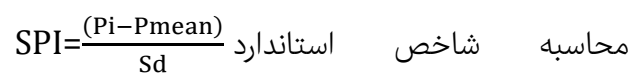
=SPi

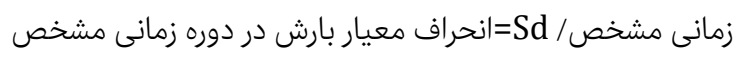

يافتههاى كمّى يزوهش براى بررسى وضعيت خشكسالى براساس شاخصهاى SPI و SPEI شغل اصلى مردم شهرستان اسلامآباد غرب كشاورزى و دامدارى و عمده محصولات شهرستان غلات و حبوبات (گندم، جو و نخود) است. با توجه به اينكه كشاورزى روستاهاى اين شهرستان بيشتر به صورت ديم است در نتيجه وابستخى مستقيمى به بارندگى دارند.

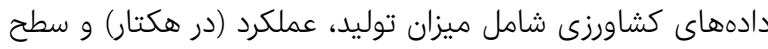
زير كشت محصولات عمده زراعى منطقه مورد مطالعه مربوط به

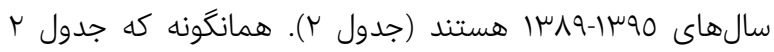

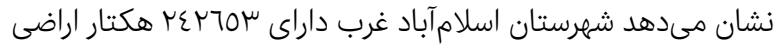

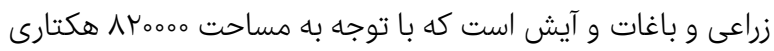

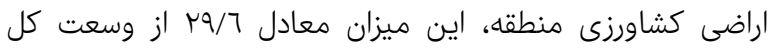

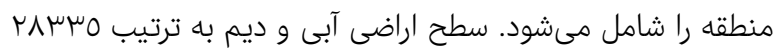

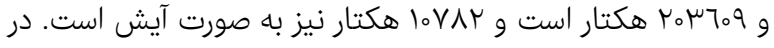

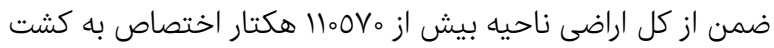

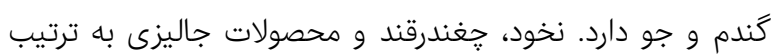
يس از غلات بيشترين سطح زيركشت را داشته كه در بين محصولات

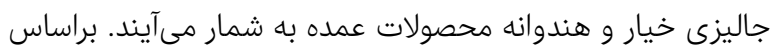

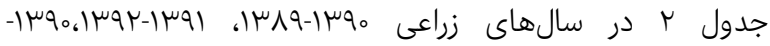

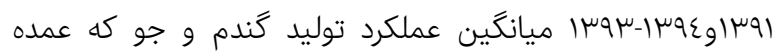
كشت زمينهاى كشاورزى به اين دو محصول اختصاص دارد 


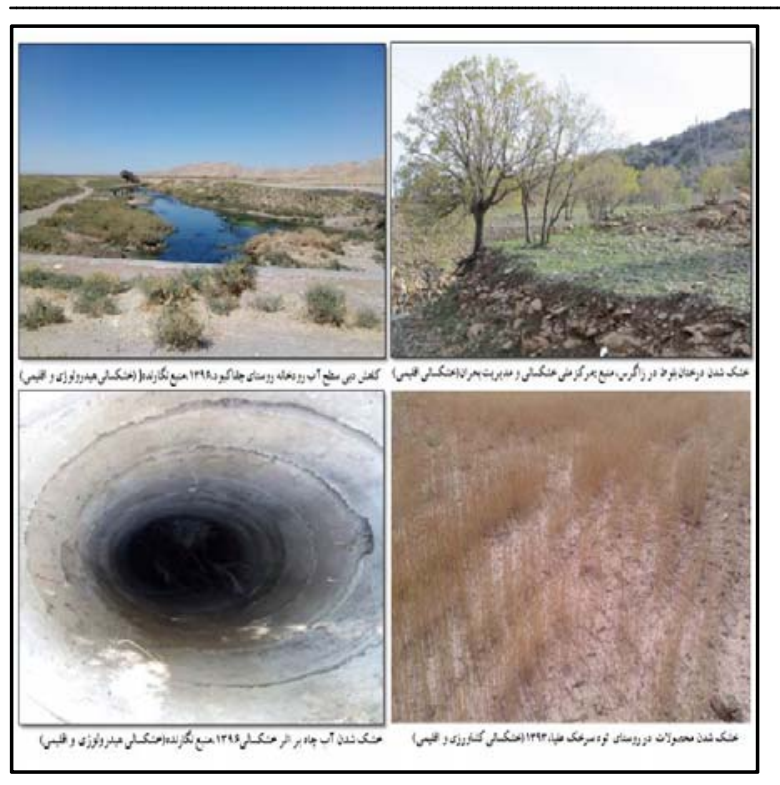

شكل r) نماهايى از خشكسالى هاى اتفاق افتاده در روستاهاى مورد مطالعه

جدول ) بارندگى ايستًاه سينويتيك شهرستان اسلام آباد غرب و محاسبه

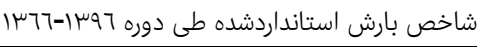

\begin{tabular}{|c|c|c|c|c|c|}
\hline Spi & سال & درجه & سال & Spi & درجه \\
\hline -。//r人१7 & IrAr & ملايم & 147 & 1/1919ع & ترسالى \\
\hline I/TrVANI & I & شدسالى & VIV & $-0 / / \mu \varepsilon_{0} 7$ & ملايم \\
\hline ०/IV7.|ع & $\mathbb{I}^{\mathrm{N}} \wedge \varepsilon$ & ن نرمال & גו & ॰/^૧૮૧ร१ & نرمال \\
\hline ०/ҮาจะТ & irso & نرمال & 11479 & ॰/979/r & ملايم \\
\hline$-1 / 17 \varepsilon 0 r$ & IrAT & متوسط & $1 \pi \gamma_{0}$ & 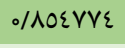 & نرمال \\
\hline$-1 / \tau_{0} \varepsilon 0 V$ & IrAV & شديد & $|r v|$ & 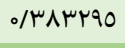 & نرمال \\
\hline -o/|£TrAI & IrAג & ن نرمال & IrVr & & ترسالى \\
\hline - I/YKAYK & $1 \% \wedge 9$ & متوسط & IrV & 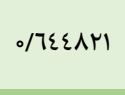 & شرسالى \\
\hline$\circ / V \varepsilon \circ V r$ & $1 \% q 0$ & نرمال & $1{ }^{\mu} V \varepsilon$ & $\circ / 1 \Lambda \circ \vee \Lambda$ & ملايم \\
\hline 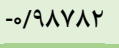 & $\mid$ |mq| & ملايم & Irvo & o/A.T०Y & ملايم \\
\hline س & Irqr & ن نرمال & I & l/AorarA & ترسالى \\
\hline -I/YAYV & س & متوسط & Irv & $-0 / \mu\urcorner \mu \varepsilon \mu$ & ملايم \\
\hline 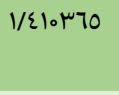 & $1 \% q \varepsilon$ & متوسط & I Ir & דות & شديد \\
\hline 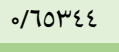 & 1790 & 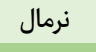 & $1{ }^{m} \mathrm{Vq}$ & -o/AVIس & ملايم \\
\hline \% \%Arr & 11497 & 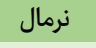 & $\mathbb{H}^{\mu} \Lambda_{0}$ & $-1 / 0 \varepsilon \mid \mu \varepsilon$ & متوسط \\
\hline- & - & - & $|m \wedge|$ & \%Vlorm & نرمال \\
\hline
\end{tabular}

\section{محاسبه شاخص بارندگى- تبخير و تعرّق استانداردشده (Spei)}

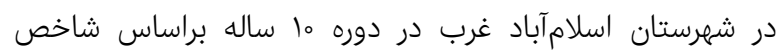

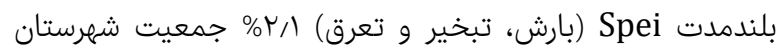

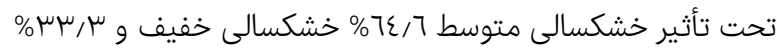

$$
\text { در شرايط نرمال قرار دارد (نمودار () ). }
$$
براى باسخ به وضعيت عوامل مؤثر بر مديريت خشكسالى از آز آزمون

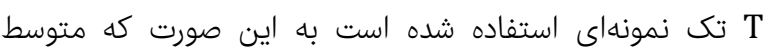

بFF

براساس تجزيه و تحليل دادههاى آمارى از ايستكاه سينويتيك اصلى

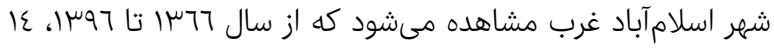

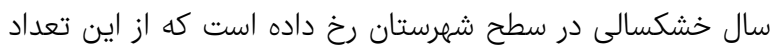

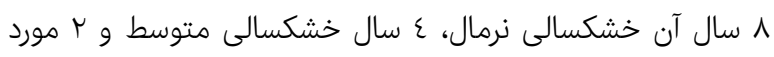

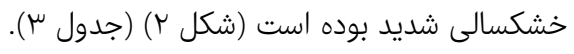

جدول r) ويزَّىهاى محصولات زراعى مطالعه شده ميانكين سالهاى 9 وسا$1 \% 19$

\begin{tabular}{|c|c|c|c|c|c|}
\hline $\begin{array}{c}\text { عملكرد درتار } \\
\text { (كيلوگرم) }\end{array}$ & $\begin{array}{c}\text { ميزان توليد } \\
\text { (تن) }\end{array}$ & سطح زير & آبى/ ديم & نام محصول & نوع \\
\hline E.rT & rquq。 & $V \mu_{\circ}$ & آبى & \multirow{2}{*}{ كندم } & \multirow{6}{*}{ سال زراعى } \\
\hline 700 & rqvooo & $\varepsilon 9000$ & ديم & & \\
\hline$\varepsilon \varepsilon_{0}$ & $1\{97$ & $\mu \varepsilon_{0}$ & آبى & \multirow{2}{*}{ جو } & \\
\hline 1100 & 170.0 & 10.0 & ديم & & \\
\hline Mroo & 9100 & rooo & \multicolumn{2}{|c|}{ ذرت دانهاى } & \\
\hline rrro.o & 0.000 & $\varepsilon 70 \circ$ & \multicolumn{2}{|c|}{ جغندر قند } & \\
\hline$\sum V_{0 \circ}$ & Tوسر & 771. & آبى & \multirow{2}{*}{ كندم } & \multirow{6}{*}{ سال زارعى } \\
\hline 0.0 & riovo & $\varepsilon \mu l O$ & ديم & & \\
\hline$\varepsilon \wedge \circ 0$ & $\Lambda \varepsilon_{0}$ & IVo & آبى & \multirow{2}{*}{ جو } & \\
\hline 10. & irkro & $17 r 70$ & ديم & & \\
\hline$\wedge 100$ & ork。 & 700 & \multicolumn{2}{|c|}{ ذرت دانهاى } & \\
\hline 00000 & rroooo & $\varepsilon 000$ & \multicolumn{2}{|c|}{ جغندر قند } & \\
\hline EHoO & rq.q1 & $77 \Lambda_{0}$ & آبى & \multirow{2}{*}{ كندم } & \multirow{6}{*}{ سال 19-99 } \\
\hline $7 V \circ$ & ro77l & 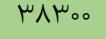 & ديم & & \\
\hline rovo & ITI & $I V \varepsilon$ & آبى & \multirow{2}{*}{ جو } & \\
\hline $0 \wedge 。$ & ITrEV & r1110 & ديم & & \\
\hline 9000 & $07 V$. & $7 \mu_{0}$ & \multicolumn{2}{|c|}{ ذرت دانهاى } & \\
\hline 07000 & 111170 & ס סזس & \multicolumn{2}{|c|}{ جغندر قند } & \\
\hline$\varepsilon 71 \varepsilon$ & rrrqu & Vooo & آبى & \multirow{2}{*}{ كندم } & \multirow{6}{*}{ سال זq-سو } \\
\hline 1100 & $\varepsilon r q_{0}$ & $\mu q_{000}$ & ديم & & \\
\hline$\varepsilon 000$ & 700 & 10 & آبى & \multirow{2}{*}{ جو } & \\
\hline VIسו & 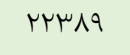 & IVooo & ديم & & \\
\hline 9000 & rroo & roo & \multicolumn{2}{|c|}{ ذرت دانهاى } & \\
\hline 00000 & rIINOO。 & $\varepsilon r V$ & \multicolumn{2}{|c|}{ گغندرقند } & \\
\hline rTooo & $\varepsilon 000$ & 70.0 & آبى & \multirow[t]{2}{*}{ كندم } & \multirow{6}{*}{ سال سو-ع؟ } \\
\hline MI人民。 & $0 \leqslant 7$ & $\varepsilon 0000$ & ديم & & \\
\hline $1 \wedge \varepsilon 0$ & $\mu 790$ & 0.0 & آبى & \multirow{2}{*}{ جو } & \\
\hline 1.00 & roo & rmoo & ديم & & \\
\hline 009 & $\wedge 70 \circ$ & 70 & \multicolumn{2}{|c|}{ ذرت دانهاى } & \\
\hline ro9111 & orO०० & щᄉн。 & \multicolumn{2}{|c|}{ جغندرقند } & \\
\hline$\varepsilon \varepsilon \wedge 。$ & $r \varepsilon\rceil \varepsilon_{0}$ & 0000 & آبى & \multirow{2}{*}{ كندم } & \multirow{6}{*}{ سال ع-909 } \\
\hline $1 \varepsilon \Lambda_{0}$ & 09 roo & $\varepsilon 0000$ & ديم & & \\
\hline$\varepsilon \mu_{\circ}$ & 10.0 & mo. & آبى & \multirow{2}{*}{ جو } & \\
\hline IVoo & $\mu \varepsilon_{000}$ & roooo & ديم & & \\
\hline 1000 & $1 r_{00}$ & 100 & نهاى & ذرت د & \\
\hline $0 \varepsilon_{0 \circ 0}$ & $19 \varepsilon \varepsilon 00$ & $\mu 700$ & ر رقند & جغند & \\
\hline
\end{tabular}




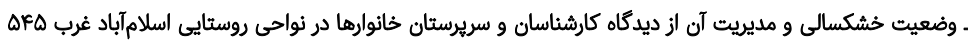

$\sum_{j=1}^{n} p i j \sum_{j=1}^{n} p i j$

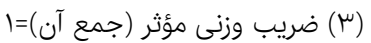

$\mathrm{ai}=\sum_{j=1}^{n}$ Woi $=1$

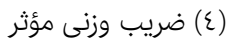

$W o i=\frac{a i}{A}$

(0) ميانكين ضريبهاى وزنى (0)

ابتدا با دريافت امتياز متغيرها از ديد كارشناسان، وزن مؤثر هر

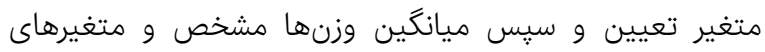
يايينتر از ميانكين حذف و متغيرهاى داراى ضريب مين برابر و بيشتر

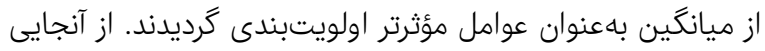

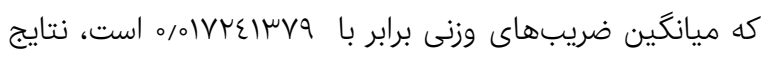

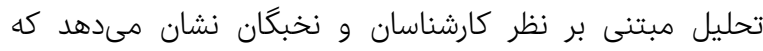

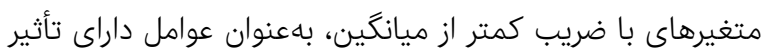

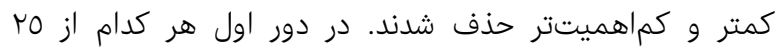
كارشناس مربوطه نظرات خود را در زمينه عوامل اثرگذار بر مديريت خشكسالى در نواحى روستايى بيان كردند. محققين و دو نفر استاد

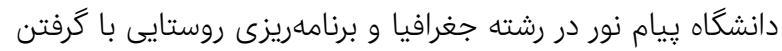

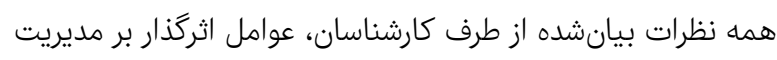
خشكسالى را كه نتيجه دور اول بود، با تلفيق از طرف محققين،

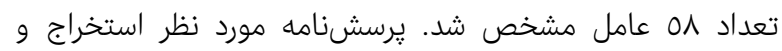

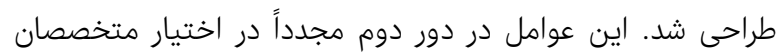

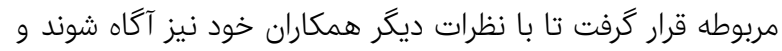

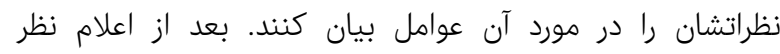

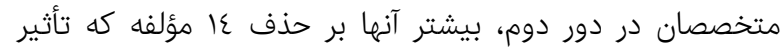

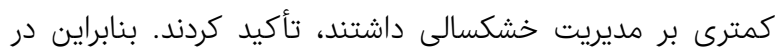

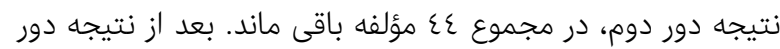

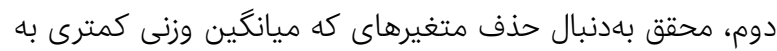

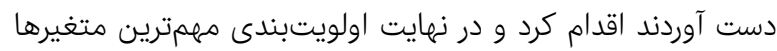

براساس ميانگين وزنى براى دور سوم صورت گرفت (جدول 0)

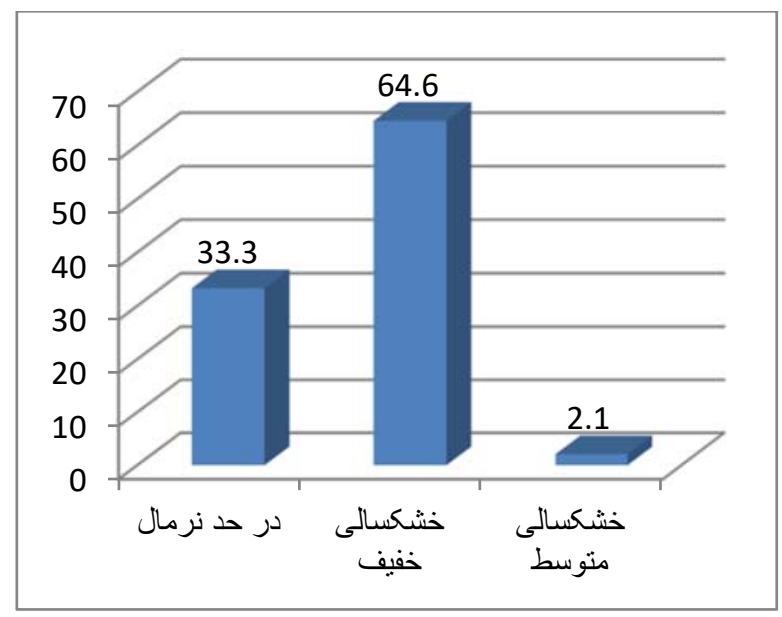

نمودار () درصد مساحت تحت تأثير خشكسالى براساس شاخص SPEI
سئوالات جهت محاسبه سطح استاندار وضعيت مناسب مديريت

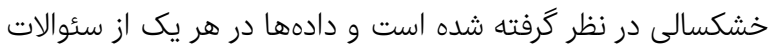

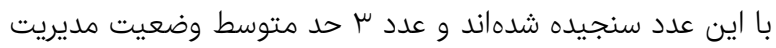
خشكسالى را نشان مىدهد. نتايج جدول ع نشان مىدهد كه وضعيت عوامل مؤثر بر مديريت

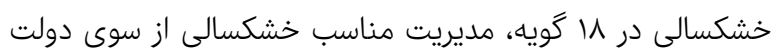

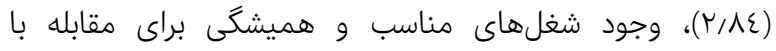

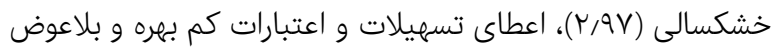

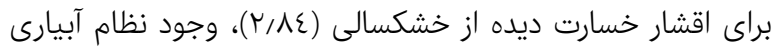
مناسب و زيرساختهاى مورد نياز در بخش كشاورزى (Y/90)، بالابودن سطح دانش مهارت و فناورى كشاورزان در زمينه مديريت

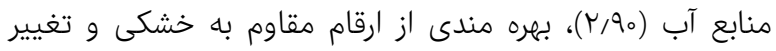

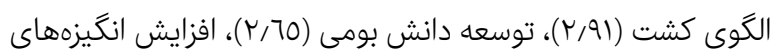

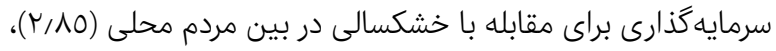

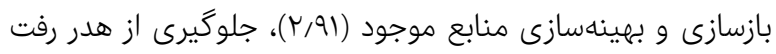

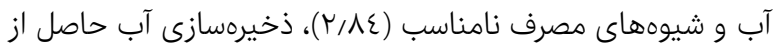

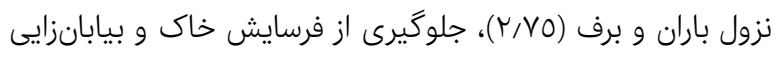

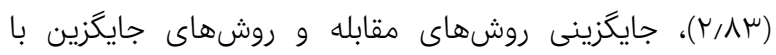

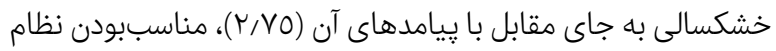

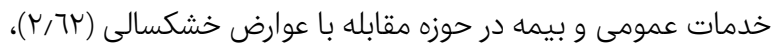

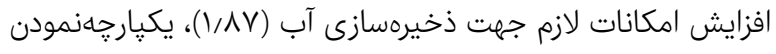

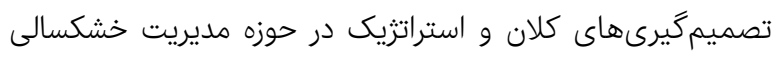

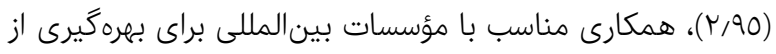

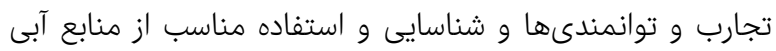

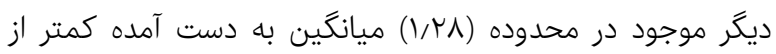

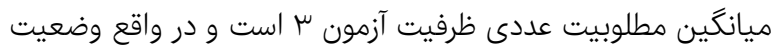

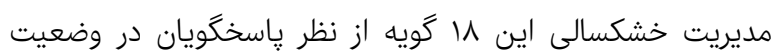
مناسب و مطلوبى نيست (جدول ع).

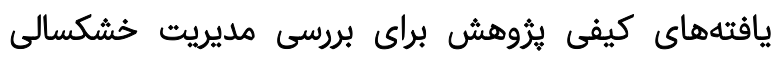

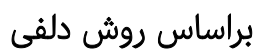

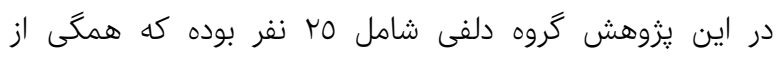

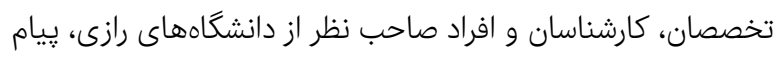

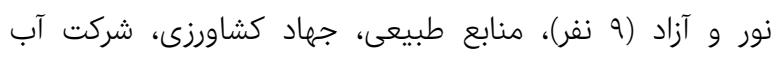

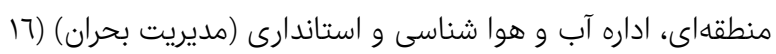

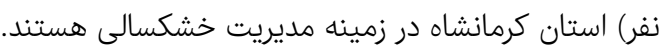

روش محاسبه دلفى ضريب وزنى مؤثر است كه بايستى جمع آن به عدد يك برسد

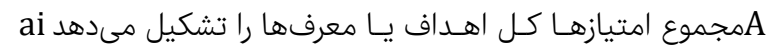

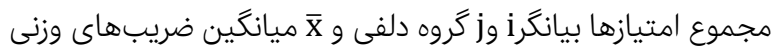
هستند. (r) مجموع امتيازها بيانكر i و j كُروه دلفى $\mathrm{ai}=\sum_{j=1}^{n} \mathrm{pij}=1$ 
جدول ع) بررسى وضعيت عوامل مؤثر بر مديريت خشكسالى براساس آزمون t تك نمونهاى (مطلوبيت عددى ظرفيت مورد آزمون برابر باس س)

\begin{tabular}{|c|c|c|c|c|c|}
\hline \multicolumn{2}{|c|}{ فاصله اطمينان 90/。 } & \multirow{2}{*}{ ميانكين به دست } & \multirow{2}{*}{ تفاوت از حد مطلوب } & \multirow{2}{*}{ سطح معنادارى } & \multirow{2}{*}{ سئوالات يرسشنامه } \\
\hline 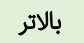 & 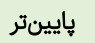 & & & & \\
\hline 1/\%VO\& & Vorr & 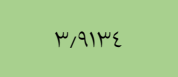 & .91हरq & .00 & 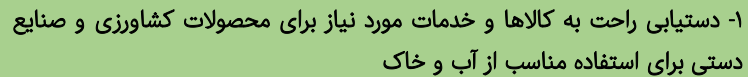 \\
\hline$-.1 \% 0 \mathrm{r}$ & $-\mu \circ \nu_{1}$ & r/A々Kq &.$- .10 \mathrm{VI}$ & . & ץ- مديريت مناسب خشكسالى از سوى دولت \\
\hline $.1 V \varepsilon \mu$ & - & r/qV/E & -.0 HAOV &.$\vee \Lambda_{0}$ & ץ- وجود شغلهاى مناسب و هميشكى براى مقابله با خشكسالى \\
\hline . TME & rrov & H/EY人T & Error & . .00 & مقابلهاى مختلف بودن منابع توليدى همراه با بيامدهاى خشكسالى با وجود نبود طرحهاى \\
\hline $1 / 0079$ &.$\wedge r \wedge q$ & r/q६rq & $.9 \varepsilon r \wedge\rceil$ & .000 & 0- تأمين اعتبارات لازم در نظام بودجهريزى براى طرحهاى مديريت خشكسالى \\
\hline $.0 \mathrm{Al \Lambda}$ &.$- \mu 971$ & r/AERq & $-.10 \mathrm{~V} / \varepsilon$ & $.19 \varepsilon$ & خ- اعطالى تسهيلات و اعتبارات كم بهره و بلاعوض براى اقشار خسارت ديده از \\
\hline .7170 & $.1 \% \gamma \mu$ & $\mu, \mu \bigvee l \varepsilon$ & ${ }^{\mu} \bigvee(\varepsilon \mu$ & $.00 \psi^{\mu}$ & V- يرداخت يارانه و حمايت از سرمايه گذارى و كارآفرينى در مناطق خشكسالى زده \\
\hline 1/19६0 & . & $\mu / 71 \varepsilon \mu$ & $71 \varepsilon r q$ & Ar & 1- مشاركت روستاييان و عشاير در برنامهريزىهاى مربوطه در حوزه مديريت خشكسالى \\
\hline.$\varepsilon 109$ & .0079 & $\mu, \tau Y \ell \varepsilon$ & rYI乏 & $.01 \varepsilon$ & 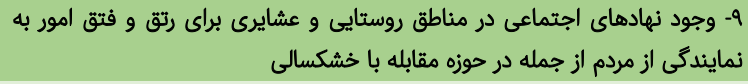 \\
\hline $.0 \mathrm{YrI}$ & IErT & r,movi & rovis & .001 & •ا- زمينه سازى كاهش ييامدهاى خشكسالى \\
\hline 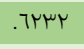 & roro & $\mu / \varepsilon \mid \varepsilon \mu$ & $\varepsilon 1 \varepsilon r q$ & .00 & 11- روند تحول از كشاورزى و دامدارى سنتى به شيوههاى نوين \\
\hline .7 .91 & $.17 r \mu$ & 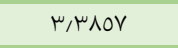 & ruovi & .001 & rا- مناسب بودن روشهاى مصرف رايج در روستاها \\
\hline $.10 \mathrm{rr}$ &..$- \mu \mu q 7$ & r/90VI &..$- £ Y \wedge T$ & .770 & سرا- وجود نظام آبيارى مناسب و زيرساختهاى مورد نياز در بخش كشاورزى \\
\hline .1110 &.$- \mu 110$ & $r / 9000$ & -.10000 & . $\varepsilon q$ & عا- بالابودن سطح دانش، مهارت و فناورى كشاورزان در زمينه مديريت منابع آب \\
\hline .1001 & $-\mu \% 10$ & $r / 91 \varepsilon \mu$ &.$- .10 \mathrm{VI}$ & $. \varepsilon V)$ & 10- بهرهمندى از ارقام مقاوم به خشكى و تغيير الكوى كشت \\
\hline r rol & .0707 & r/190\% & $.190 \% 1$ &.$\circ \mu$ & 17- بهبود برنامههاى آموزشى ترويجى در زمينه مديريت منابع آب در بخش كشاورزى \\
\hline$-.11 \gamma^{\mu}$ & -.0710 & r/70ri &.$- \mu \varepsilon r \Lambda T$ & $.0 \%$ & 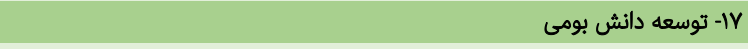 \\
\hline.$\vee \vee \uparrow$ &.$- \mu$ Tro & r/AOVI & $-.1 \varepsilon \uparrow \wedge \uparrow$ & .199 & 1|- افزايش انكيزههاى سرمايهذارى براى مقابله با خشكسالى در بين مردم محلى \\
\hline.$\vee \varepsilon \vee q$ & $.09 . \mathrm{V}$ & $\mu / \varepsilon \vee \varepsilon_{0}$ & . $7794 \mathrm{Y}$ & .00 & 19- جلوكيرى از هم باشيدگى وحدت بين افراد و جوامع روستايى و عشايرى \\
\hline $.0 \wedge \mathrm{V} 7$ & 虫 & ץ/Аноя & $.2 \vee \mu 97$ & .00 & •ץ- ترويج و آموزش فنون و روشهاى صحيح گردش، توزيع و مصرف آب آبيارى \\
\hline $.9 \mathrm{rol}$ & $. \vee \varepsilon\rceil V$ & r/oor & . & .00 & اب- توسعه زيرساختها و شبكههاى آبيارى و آبرسانى سازگار با شرايط محلى \\
\hline 1/100 & . $10 ₹ 7$ & r/o 7ro & ऍ/৭१६А & .00 & براى مقابله با خشكسالى از ظرفيت مؤسسات بُوهشى، مراكز دانشكاهى و دستكاههاى اجرايى \\
\hline$\mu \varepsilon 70$ & $-.01 \mu r$ & $r / 9191$ &..$- \wedge \mu \mu \mu$ & .794 & سץץ- بازسازى و بهينهسازى منابع موجود \\
\hline .0701 & $-\mu \curlyvee \varepsilon \varepsilon$ & Y/АERQ &.$- \vee \varepsilon \varepsilon$ & $.10 \varepsilon$ & عץ- جلوگيرى از هدر رفت آب و شيوههاى مصرف نامناسب \\
\hline.- .0011 &.$- \varepsilon \vee \vee q$ & rivori &.- YYYAT &.$\circ \mu$ & مr- ذخيرهسازى آب حاصل از نزول باران و برف \\
\hline WEAT & 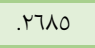 & $\mu, \nu_{\circ} \wedge \mu$ &.$\vee \circ \wedge \mu \mu$ & .001 & Tr- افزايش مناطق حفاظت شده و جلوكيرى از تخريب آنها \\
\hline.$- .2 \mu \omega$ & $-\mu_{0 \circ 7}$ & r/AイAI & $-.1 \mathrm{~V} / \mathrm{\Lambda \Lambda}$ & .009 & 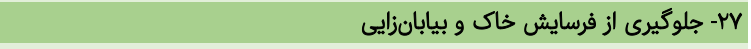 \\
\hline אוזרץ & $1 / 009 \mathrm{Y}$ & $\varepsilon / 7710$ & $1 / 171 \varepsilon 7$ & .00 & 1Y- مبارزه با هجوم آفات و بيمارىهاى گياهى و مرتعى \\
\hline $.11 \% 9$ & $.07 \%$ & r/ тAvo & $.7 \mathrm{Y} \mathrm{O}_{0}$ & .00 & وץ- تنوع گونههاى گياهى و جلوگيرى از بين رفتن آنها \\
\hline.$৭ \varepsilon \vee \varepsilon$ & $. V \mid \varepsilon_{0}$ & $/ \wedge \mu_{\circ} \vee \gamma$ &.$\wedge \mu \circ \vee \mu$ &. .00 & 。ـ- وجود طرح جامع و راهبردى براى مديريت يكيارحه خشكسالى \\
\hline.$r \mathrm{r} \wedge$ & $.1 T V \varepsilon$ & r,rort & rorto & .000 & اس- توسعه زيرساختهاى توسعهاى مديريت خشكسالى در مناطق روستايى \\
\hline.$- .0 \% \mu$ & $\mu_{0} \varepsilon_{0} / \mu$ & K/AROQ & $-.17 \varepsilon_{0} 7$ & (0) & بيامدهاى آنزينى روشهاى مقابله و روشهاى جايكزين با خشكسالى به جاى مقابل با \\
\hline $1 / 0 \varepsilon 7 \pi$ & $.8 \wedge 19$ & 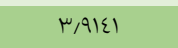 & $.91 \varepsilon 07$ & $.00 \varepsilon$ & سرس- تخمين زمان وقوع خشكسالى \\
\hline 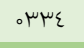 & -orme & r/voOl & $-r \varepsilon \varepsilon q_{0}$ & $\% \wedge \mu$ & عَّ- مناسب بودن نظام خدمات عمومى و بيمه در حوزه مقابله با عوارض خشكسالى \\
\hline ArVo & $.00 \mathrm{rV}$ & $\mu / 7901$ & $.790 \%$ & .00 & 0"r- مشخصبودن شيوههاى مالكيت منابع توليد(نظير اراضى مرتعى و زراعى) \\
\hline rav7 & $1 \varepsilon q \pi$ & 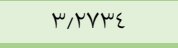 &.$T Y \mu \varepsilon \varepsilon$ &.$\cdots$ & Tس- دسترسى به مواد و زيرساختها و فناورىهاى توليد \\
\hline .0101 &.$- \vee 701$ & r/Tro。 &.$- \mu \vee 0.0$ & .009 & 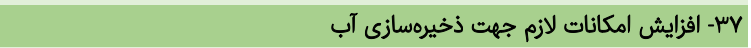 \\
\hline $1 / 0.04$ & $1, \pi 978$ & $\varepsilon, \pi q \wedge \varepsilon$ & $1, \pi 9 \wedge \varepsilon \varepsilon$ & .00 & ^ץّ- برنامهريزى توسعه سرزمين و كاربرى اراضى \\
\hline$-1 / 019 \varepsilon$ & -1, rror & l/AVVT & $-1 / 1 \% \varepsilon_{0}$ &.$\circ \mathrm{V}$ & خشكسالى \\
\hline קqv & $.1 \varepsilon q \mu$ & $\mu, \mu \gamma \mu \varepsilon$ &.$r \gamma \mu \mu \varepsilon$ & . .0 & و مح- وجود راهبرد ملى بلند مدت براى مديريت خشكسالى با كنجاندن شرايط محيطى \\
\hline ma人t & $-.2 \wedge 10$ & $r / 90 \wedge \mu$ &..$- \varepsilon 17 \gamma$ &.$\wedge \varepsilon 7$ & اع- همكارى مناسب با مؤسسات بينالمللى براى بعرهيرى از تجارب و توانمندىها \\
\hline$\mu_{0} \%_{1}$ & rqv & $\varepsilon, \mu q \wedge \varepsilon$ & $1,9 \wedge \wedge \varepsilon \varepsilon$ & .00 & آسيبــ توسعه زيرساختها و ارائه خذمات حمايتى و توسعه تأمين اجتماعى در مناطق \\
\hline . & $.1 \% \varepsilon \Lambda$ & $\mu, \mu \mu q 7$ &.$\mu \mathrm{mol}$ &.$\circ \mathrm{V}$ & رأ- هماهنگ سازى مديريت بحران خشكسالى با ديكر سياستهاى ملى و استانى \\
\hline..$- £ \mu$ &.$- \mu_{\circ \circ 7}$ & $1, r \wedge \mu r$ & $-.1 \mathrm{~V} / \mathrm{\Lambda}$ &.$\circ \Lambda$ & عـ- شناسايى و استفاده مناسب از منابع آبى ديكر موجود در محدوده \\
\hline
\end{tabular}


هFY وضعيت خشكسالى و مديريت آن از ديدكاه كارشناسان و سريرستان خانوارها در نواحى روستايى اسلامآباد غرب نومان

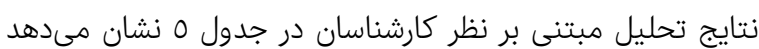

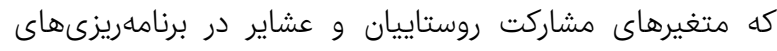

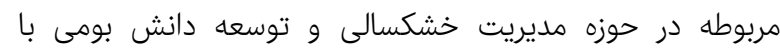

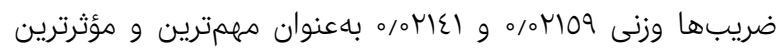

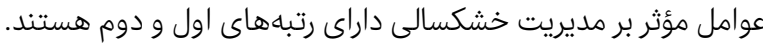

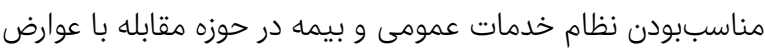

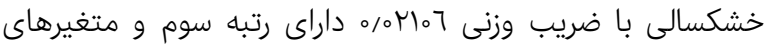
ديكر در رتبههاى بعدى قرار دارند.

تحقيق ميدانى و يافتههاى كمى در منطقه نشان از آن دارد كه

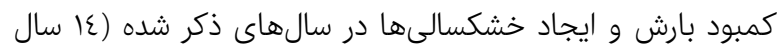

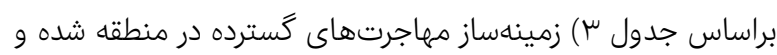

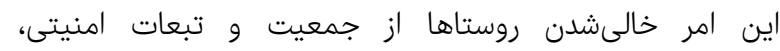

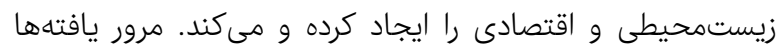

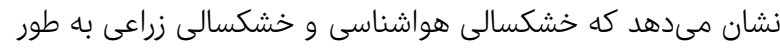

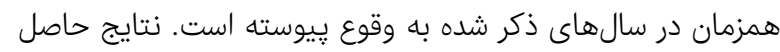

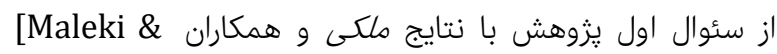
Torkmani, 2015]

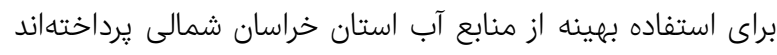

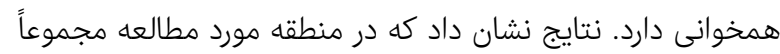

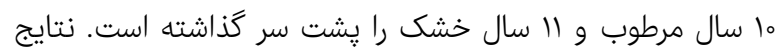

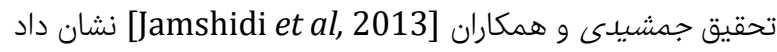

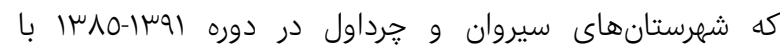

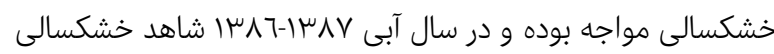

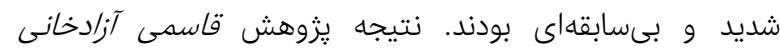

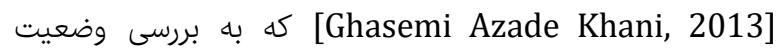

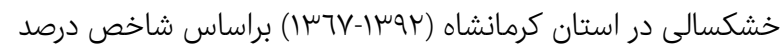

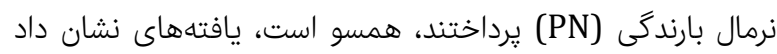

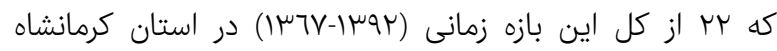

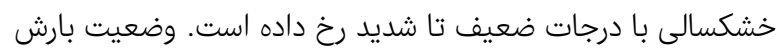

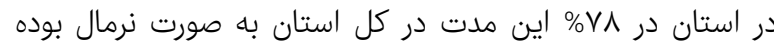

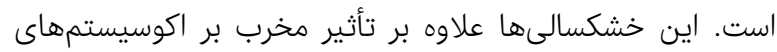

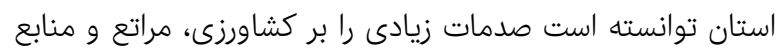

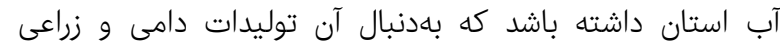
كاهشيافته و شاهد كاهش درآمد روستاييان و حتى تشديد

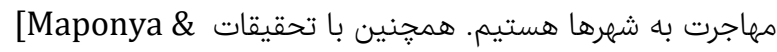
Mpandeli, 2012; Dehban et al, 2015; Yousefi et al, [2015 همسو و هم راستا است. با توجه به اين كه در بعضى العنى از

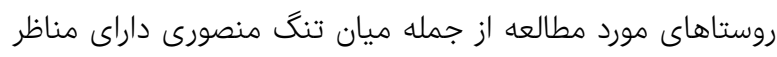

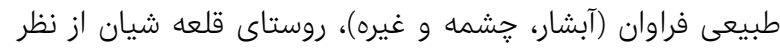

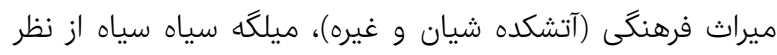

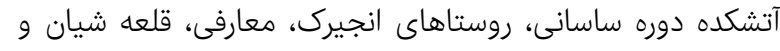

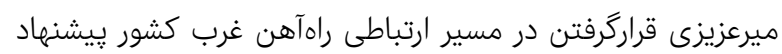

\begin{tabular}{|c|c|c|c|}
\hline نتيجه & Woi & ai & سئوالات \\
\hline & & & اقتصادى \\
\hline IV & \%OYAYYA. & 101 & 1 \\
\hline حذف ح ح ح ح & q a & vV & r \\
\hline 18 & $\%$ & 1.r & $\mu$ \\
\hline Q & \% Y०V०マ৭९Q & IIV & k \\
\hline 11 & 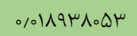 & $1 . \mathrm{V}$ & $\Delta$ \\
\hline حذف حف & 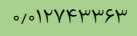 & vr & 4 \\
\hline$\wedge$ & ०/19人ץ\%००q & $\| r$ & v \\
\hline 11 & $\circ / 0 / \wedge q \mu \wedge . \Delta \mu$ & $10 \mathrm{~V}$ & $\wedge$ \\
\hline \multirow[t]{2}{*}{ ro } & \% /VIVKkalr & 91 & 9 \\
\hline & & & اجتماعى \\
\hline حذف & \%/llQ.kkra & 70 & 10 \\
\hline 1 & \% rlaquar & Irr & 11 \\
\hline ir & $0 / 01 \wedge V 91.9 Y$ & 107 & ir \\
\hline حذف & $\% / 1 H_{0} q \gamma \mu k \Delta$ & $v \varepsilon$ & ir \\
\hline حذف & \%olrarorak & $\gamma \mu$ & If \\
\hline if & $\circ / 0 \mid \Lambda F_{0} V_{0} \Lambda$ & $1 . \varepsilon$ & 10 \\
\hline$r_{0}$ & $\%$ & 91 & 18 \\
\hline is & \%1Vצ99110 & 100 & IV \\
\hline ז & $\left.\% \wedge \wedge \Delta \wedge \wedge k_{0}\right\rangle \mid$ & 100 & u \\
\hline k & $\%$ \%०AAKqDS & 114 & 19 \\
\hline 11 & $\circ / 0 / \wedge q \mu \wedge . \Delta \mu$ & lov & ro \\
\hline$\pi$ & \%OIXVAl.GY & 107 & r \\
\hline r & \% YIFIQQYq & $|M|$ & $r r$ \\
\hline حذف & \%olrakrrol & vq & $r \mu$ \\
\hline 18 & $\circ / 1 \Lambda_{0} \Delta \mu_{0} q Y$ & lor & KK \\
\hline حذف & \%OllsN|F|E & 77 & ra \\
\hline حذف & /01 & vr & re \\
\hline iv & \%olvAValos & 101 & rV \\
\hline$\Delta$ & \% Y०V॰V৭ৎQ & IIV & ru \\
\hline 9 & 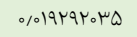 & 109 & rq \\
\hline حذف & \%olkiهqrar & ᄉ. & $\mu_{0}$ \\
\hline \multirow[t]{2}{*}{9} & \% Y.romqAY & 110 & ו \\
\hline & & & زيست محيطى \\
\hline iv & \%olvAVslos & 101 & $\mu r$ \\
\hline 1. & $0 / 1911 Q_{0} k K$ & 101 & سر \\
\hline v & \% Y.IVद991 & $\| \varepsilon$ & $\mu F$ \\
\hline 9 & 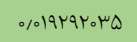 & 1.9 & $\mu \Delta$ \\
\hline 10 & 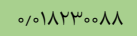 & 1.4 & rq \\
\hline 19 & \%OVATMITK & 99 & $\mu v$ \\
\hline \multirow[t]{2}{*}{19} & $\left.\% / 1 \Lambda_{\circ} \Delta \mu_{0} q\right\rangle$ & 1.r & $\mu_{\mu}$ \\
\hline & \%olvmkalmm & १人 & نهادى-زيربنايى \\
\hline ir & \%olNVGlogr & 107 & $k_{0}$ \\
\hline 1. & $0 / 01911 Q_{0} k K$ & 101 & $k_{1}$ \\
\hline 18 & $\% / 1 \Lambda_{0} \Delta \psi_{0} q Y$ & 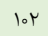 & kr \\
\hline$\mu$ & $\%$ \%l.slakV & 119 & $\mathrm{kr}$ \\
\hline « & \%olvsqa11a & 11 & $k k$ \\
\hline ז & $\%$ & 107 & $k \Delta$ \\
\hline حذف & \% 10819ksa & T. & kq \\
\hline I & $\% / 0 \wedge \Delta \wedge \wedge K_{0} \vee V \mid$ & 100 & $\mathrm{kV}$ \\
\hline حذف & \%००9VHFalr & $\infty$ & kA \\
\hline حذف & 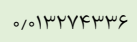 & vo & $\mathrm{kq}$ \\
\hline حذف & o/lllQ $Q_{0} k r$ & אד & $\omega_{0}$ \\
\hline 19 & \%olvarmite & 99 & هI \\
\hline حذف & 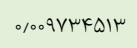 & $\infty$ & $\Delta r$ \\
\hline$\wedge$ & 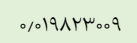 & $\| r$ & $\Delta \mu$ \\
\hline if & $\% \circ\rangle\left\langle Y_{0} V_{0} \Lambda\right.$ & lo & $\Delta F$ \\
\hline is & 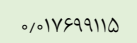 & 100 & $\Delta Q$ \\
\hline 1. & $0 / 01911 D_{0} k k$ & 101 & $\Delta S$ \\
\hline ז & $\left.\% / \wedge \Delta \wedge \wedge k_{0}\right\rangle \mid$ & 100 & $\Delta v$ \\
\hline iv & $\% / 1 Y \wedge Y 91.8$ & 101 & $\Delta \wedge$ \\
\hline
\end{tabular}




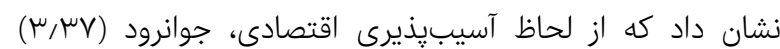

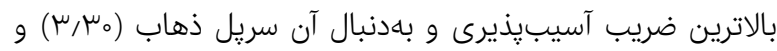

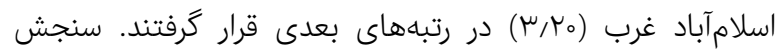

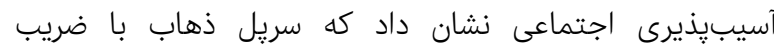

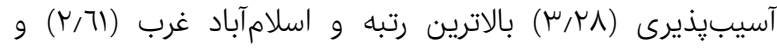

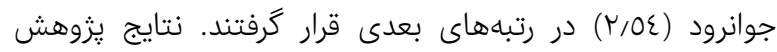

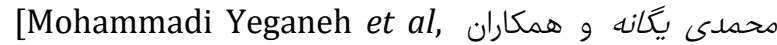
[2012 كه در مقالهاى به واكاوى تأثيرات خشكسالى بر اقتصاد

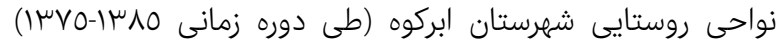
يرداختهاند، همسو بوده كه نتايج نشان از آن دارئ دارد كه اين شهرستان إنتان

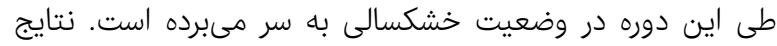

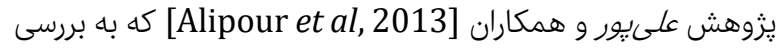
اثرات خشكسالى بر وضعيت اقتصادى اجتماعى كشاورزان نهبندان، يرداختهاند همسو بوده كه به اين نتيجه رسيدند كه اثرات خشكسالى

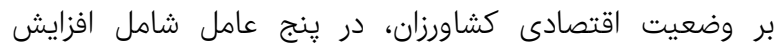

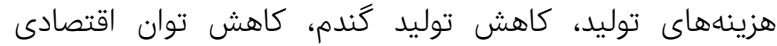

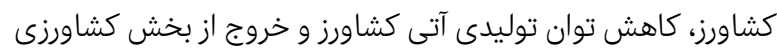

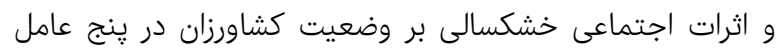

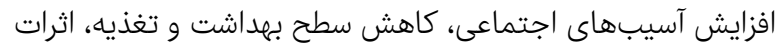

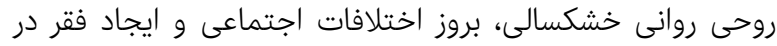

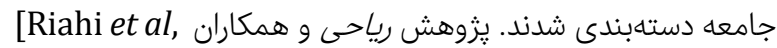
[2013، نشان داد كه خسارت ناشى از خشكسالى در كاهش درآئن

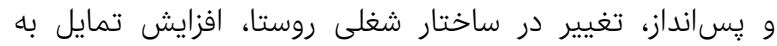
مهاجرت در روستا، كاهش مشاركت و روابط اجتماعى، كاهش دارئ دامها

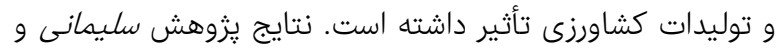
همكاران [Soleimani et al, 2018] كه به بررسى تأثير

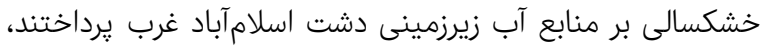

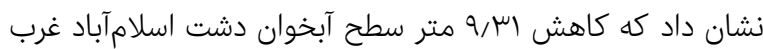

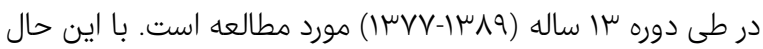

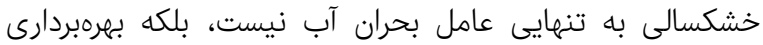

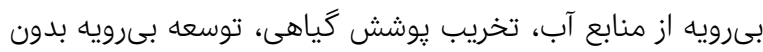

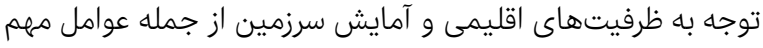

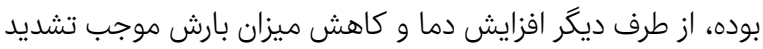

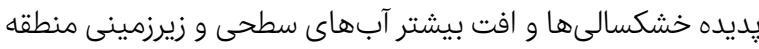

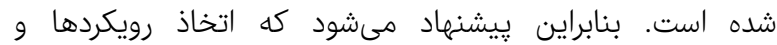
سياستهايى هم جون تغيير الخَّى كشت، برداخت يارانه، بيمه محصولات كشاورزى و دامى و غيره، اعطاى سهل الوصول اعتبارات

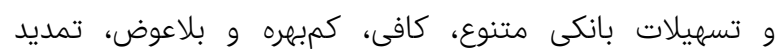

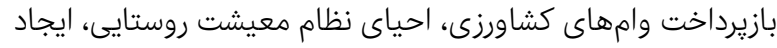

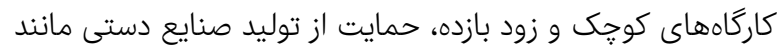

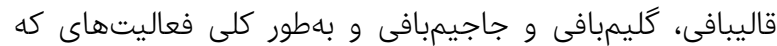

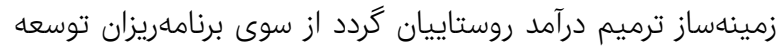

روستايى مورد توجه جدى قرار كيرد. در قسمت كيفى نتايج تحليل مبتنى بر نظر كارشناسان نشان
مى شود كه تنوع شغلى و سرمايهذارى در بخش كشاورزى، دامدارى

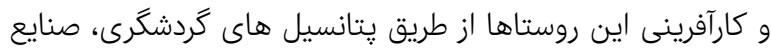

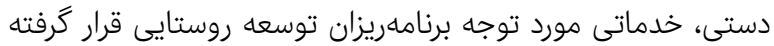

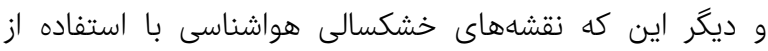
شاخصهاى خشكسالى SPEI، SPI و غيره در دسترس تماري سازمانهاى مربوطه قرار گيرد و براساس آن تصميمات لازم اتخاذ درد

در بررسى وضعيت موجود شاخصهاى اجتماعى، اقتصادى،

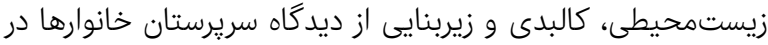

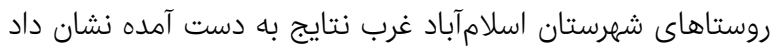

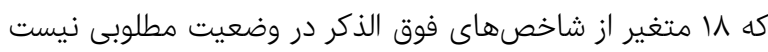

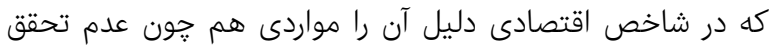

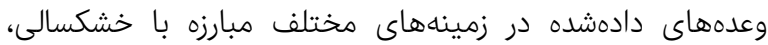

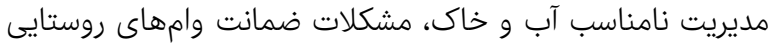

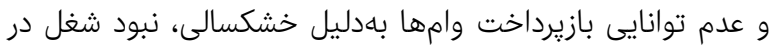
كنار كارهاى كشاورزى و دامدارى و فصلى فيودن برخى إز إز شغلها

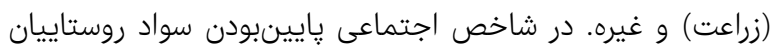

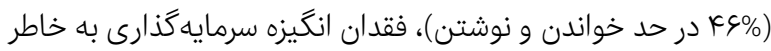

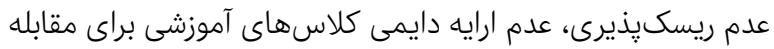

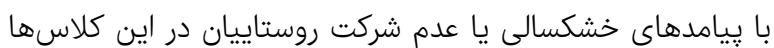

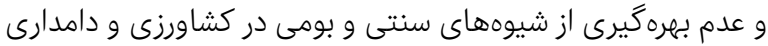

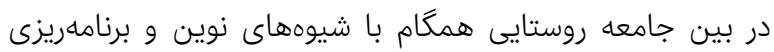

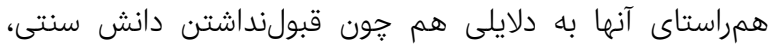

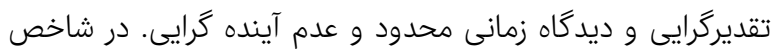

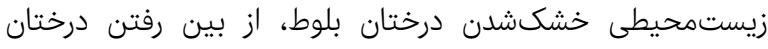

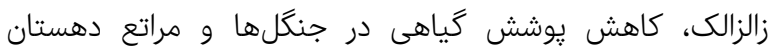

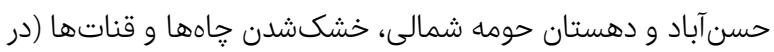

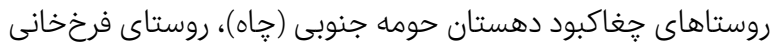

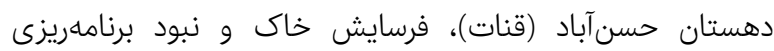

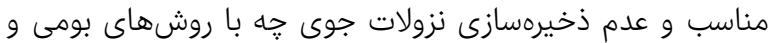

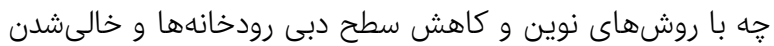

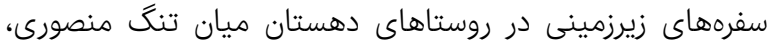

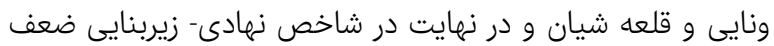

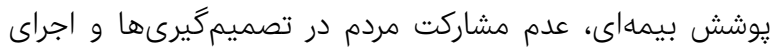
برنامهها توسعهاى (رويكرهاى مشاركتى) ذكر كرد.

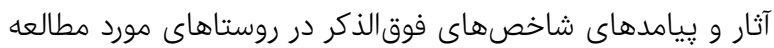

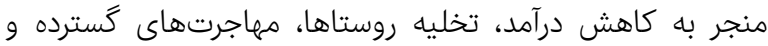

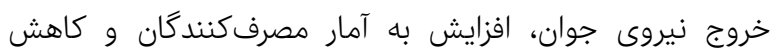
توليدات، افزايش بزهكارى، فروياشى اقتصاد محلى و محيط زيست

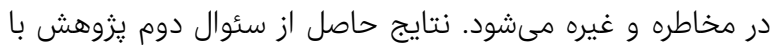

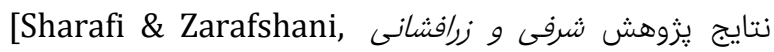

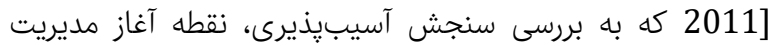
ريسك در خشكسالى مطالعه موردى: شعرستانهاى سريل ذريل ذهاب، اسلامآباد غرب و جوانرود يرداختند، همسو و همراستا است، نتايج 


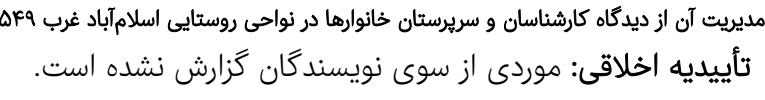

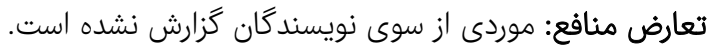

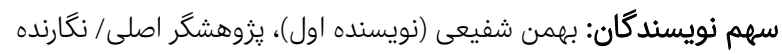

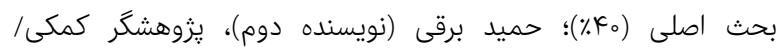

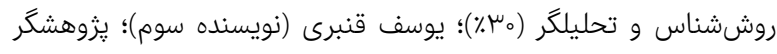

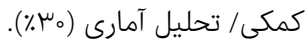

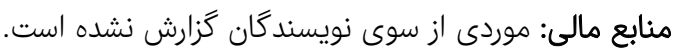

منابع

Alavizadeh AM, Izadi A (2018). Analysis of the effects of drought on the economic structure of rural household, case: Kavir villagein district of Khalil Abad. Journal of Rural Space Economics. 7(23):202-183. [Persian]

Agricultural Jihad Organization of Kermanshah Province [Internet] (2014). Statistics of horticultural and crop products. [Published 2014, 25 Jun, Cited 2019, 27 october]. Available from: https://kermanshah.maj.ir Alipour H, Chaharsughi Amin H, Gharib A (2013). The effects of drought on farmers' economic and social situation, case study: Wheat farmers in Nehbandan district. Watershed Research. 99:125-113. [Persian] Amir Khani S, Chizari, Hosseini M (2012). Effective factors in farmers management type, on drought Case study of Wheat farmers in Varamin county. Iranian Journal of Agricultural Economics and Development. 43(2):229223. [Persian]

Atlas of the districts of Kermanshah province (2017). The country's planning and budget organization, the Kermanshah Province Management and Planning Organization, the Deputy Director of Statistics and Information, the first edition, the publisher of the country's Planning and Budget Organization, and the Documentation and Publication Center. [Persian] Campbell D, Barker D, McGregor D (2016). Dealing with drought: Small farmers and environmental hazards in southern St. Elizabeth Jamaica. Applied Geography. 1(31):146-158.

Dehban H, Ebrahimi K, Araghinejad S (2015). Presentation and evaluation of the new index of MRDI in drought monitoring, case study: Gorgan Rood Basin. Iranian Soil and Water Research. 46(1):19-30. [Persian] Dehghanpour A, Vali MH, Rezaei H, Masumian E (2017). Drought risk management a step towards sustainable development of rural settlements case study: Ardakan district. Fourth Scientific Research Conference on Agricultural Science Development and Promotion; Natural and Environmental Iran. 2017, 5 July: Tehran. pp. 126-137. [Persian]

Dehghani A (2014). Analysis of the effects of drought on agricultural economics in rural areas. First National Conference on Agriculture, Environment and Food Security. 2014, 3 March: Jiroft. [Persian]

Elfaigh AHI (2015). Strategies to reduce drought vulnerability with special emphasis on coping strategies of the poor: Sub -Saharan Semi - arid area western Sudan. Sudan: University of Khartoum.

Esmaeili F, Khodadad M (2017). Drought risk management, and its effects on the economic recovery of rural farmers; case study: Bonab district. Journal of Applied Studies, in Management and Development Sciences. 2(4):1-8. [Persian]

Fard Moradinia S, Soleimanzadeh A (2016). Drought
مىدهد كه متغيرهاى مشاركت روستاييان و عشاير در

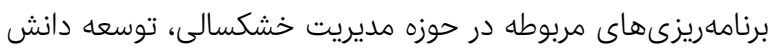

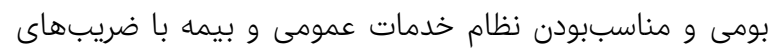

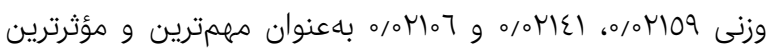
عوامل مؤثر بر مديريت خشكسالى داراى رتبههاى اول تا سوم

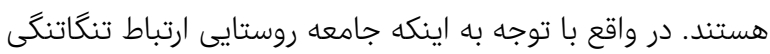

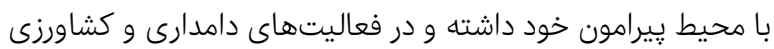
مشغول بوده و بيشترين ميزان درآمد و اشتغال آنها در اين زمينها دها دها

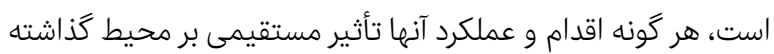

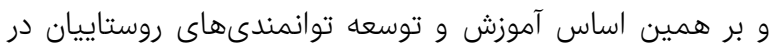

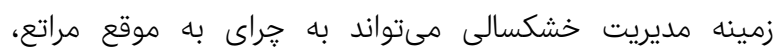

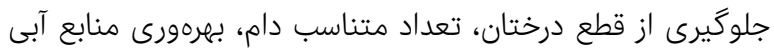

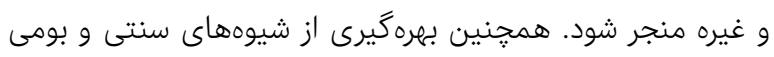

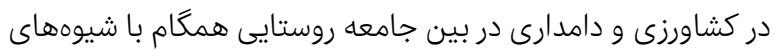

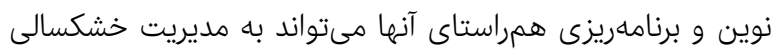
كمك شايانى نمايد. زمانى كه خدماترسانى به موقع در زمينه بروز

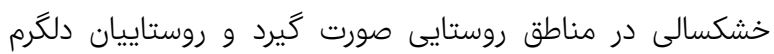

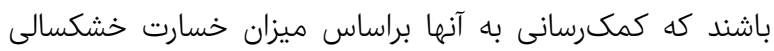

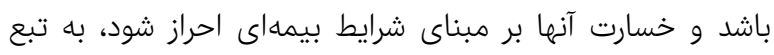

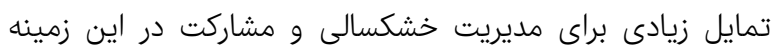
خواهند داشت تا راندمان و كيفيت محصولات كشاورزى و دامدارى ماريت

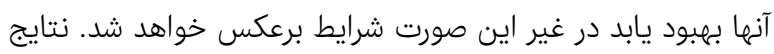

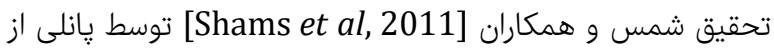

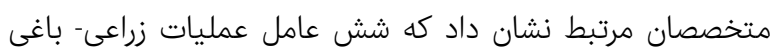
قبل از كاشت، مصرف بهينه كودها، حفظ و انتقال آب، عمليات زراعى- باغى در مرحله داشت و نهالهاى مقاوم به به ترتيب كودها، حفظ اهميت

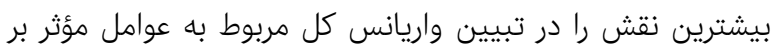

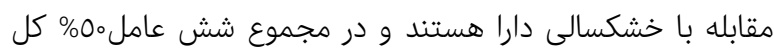

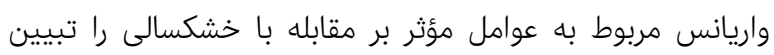

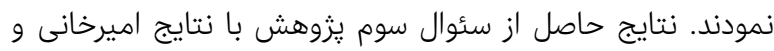

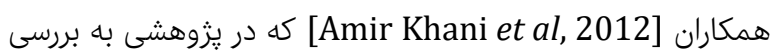
عوامل مؤثر در نوع مديريت كشاورزان در زمينه خشكسالى (مطالعه

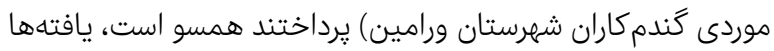

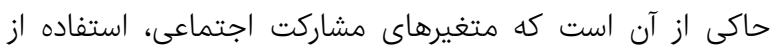

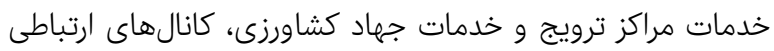
و استفاده از خدمات شركتهاى خدمات مشاورهاى فنى مهندسى

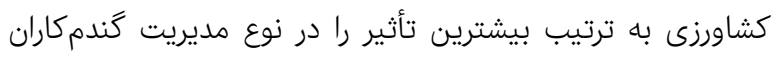

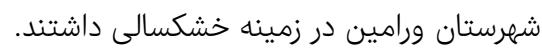

\section{نتيجه}

مشاركت روستاييان در برنامهريزىهاى حوزه مديريت خشكسالى مهمترين و مؤثرترين عامل مؤثر بر مديريت خشكسالى است. دمان. تشكر و قدردانى: موردى از سوى نويسندًان گزارش نشده است. 
Asia A retrospective analysis. Weather and Climate Extremes. 3: 54-61

Rezaei A, Mortazavi A, Peikani G (2016). Analysis of farmers' status, east of Zayandehrood basin under drought conditions. Journal of Agricultural Research \& Development. 47(2):335-342. [Persian]

Riahi V, Pasha Zadeh A (2013). The economic and social effects of drought on rural areas in the district of Germi, case study: Azad Lo village. Geographic Perspective in Human Studies. 8(25):17-37. [Persian]

Salman Shahraki, V (2015). Drought management survey among farmers in terms of rural poverty: Hirmand district. [dissertation] Ahvaz: Ramin University of Agricultural Sciences and Natural Resources. [Persian] Sadeghloo T, Arab Teymoori Y, Shakourifard E (2017). Measuring the level of knowledge and awareness of villagers about the management of drought crisis, case study: Rurals in the village of Khaf, Khaf district. Journal of Geography and Environmental Risks. 20(2):73-100. [Persian]

Shams A, Basami A, Houshmandan Moghadamfard Z (2011). Effective factor analysis, on optimal drought management, case study: Farmers in Saravabad Region, Kordestan. First National Conference on Drought and Climate Change. 2011, 5 March: Karaj. [Persian]

Sharafi L, Zarafshani K (2011). Vulnerability assessment, risk management point in drought case study: Sarpol Zahab, Eslamabad Gharb and Javanrood. Regional Planning Quarterly. 1(1):43-56. [Persian]

Sobhani B, Goldust A (2015). Drought monitoring, and its possibility estimation, in Ardebil province using the SPI index and the ANFIS model. Research Geographic Journal. 30(1):135-152. [Persian]

Soleimani S, Hayati S, Safari Z (2018). The effect of drought on groundwater resources, Eslamabad Gharb Plain. Second International Conference on Water and Environment Engineering. 2018, 18 August: Tehran. [Persian]

Mahmoudi, Seyyed M (2003). The role of information systems in crisis management, management culture. 1 (2):59-92. [Persian]

Mohammad Nia Qarai, S-Askarizad, Seyed M, Mojtaba Z (2010). Disaster management and environmental hazards planning for sustainable development, Proceedings of the Fourth International Congress of Islamic Geographers. 2010, April 25-27: Zahedan. [Persian]

Vento JPh, Reddy VR, Umapathy D (2010). Coping with drought in irrigated south India: Farmers' adjustments in Nagarjuna Sagar. Agricultural Water Management. 97(10):1434-1442.

Tarmeh, Consulting Engineers [Internet] (2006). Structural analysis structure project, in Eslamabad Gharb (Municipality of Eslamabad Gharb) [Published 2006, 1 October]. Available from: http://www.ostan-ks.ir/ [Persian]

Yazdani S, HaghSheno M (2007). Drought management and diversion strategies, 6th Iranian Agricultural Economics Conference. 2007, 8 October: Mashhad. [Persian]

Yousefi H, Nohegar A, Khosravi Z, Aziz-Abadi Farahani M (2015). Drought management and zonation using SPI \& RDI indices, case study: Markazi province. Journal of EcoHydrology. 2(3):337-344. [Persian] management, the most important part of water resources management in Iran case study of drought management focusing on comprehensive drought monitoring system. International Conference on Science and Engineering. 2016, 29 July: Turkey. pp.112-125. [Persian]

Faryabi M, Mozafarizadeh J (2017). Hydrological drought management index (HDMI), as a method for managing groundwater resources, under drought conditions, case study: Dayir-Abdan plain, Bushehr province, Ecocidology. 4(3):737-748. [Persian]

Folkman S (2018). Personal control and coping processes: A theoretical analysis. Journal of Personality and Social Psychology. 46(4): 839-852.

Ghasemi Azad Khani MS (2014). Drought status assessment in Kermanshah province (1988-2013) based on normal rainfall index (PN). Second National Conference on Environmental Hazards of Zagros. 2014, 5 March: Tehran. [Persian]

Gholami M, Ali Beigi AH (2014). Identification of native methods of drought management, case study: Sarpol Zahab district. Rural Research Quarterly. 5(3):638-611. [Persian]

Governorate of Eslamabad Gharb [Internet] (2005). Strategic development plan of Eslamabad Gharb, ministry of the Kermanshah. [Published 2005, 2 November]. Available from: https://razi.ac.ir

Hafeznia M R (2005). Introduction to the research method in humanities. Tehran: Smat. [Persian]

Hasani Nejad A, Taghdisi A, Nouri H, Akbarian Ronizi S (2018). The role of drought risk management in reducing farmers' vulnerability case study of Zarrin Dasht Township. Rural Studies Quarterly. 9(2):264-277. [Persian]

Iran's Statistics Center [Internet] (2017). Detailed results of population and housing census, Eslamabad Gharb. [Published 2016, 6 October; Cited 2019, 5 Jun]. Available from: http://mpo-ksh.ir. [Persian]

Jamshidi M, Nouri Zamanabadi H, Seydai Golsefidi E, Rahimi D (2015). The effects of drought on the economy of rural areas, Sirvan and Chardavol Township. Journal of Rural Space and Rural Development. 14(3):1-17. [Persian]

Keshavarz M, Karami E (2008). Effective structures on farmers' drought management and its consequences: application of structural equation model. Journal of Water and Soil Science. 12(43):267-283. [Persian]

Kiani Selmi S, Amini Faskhoodi A (2017). Explaining the social factors of drought and identifying its effects. Journal of Scientific-Research on Spatial Planning. 7(4):1-18. [Persian]

Maleki A, Torkmani MJ (2015). Drought management for optimal use of water resources in north Khorasan Province. Journal of Agricultural Economics Research. 7(1):65-89. [Persian]

Maponya P, Mpandeli V (2012). Climate change and agricultural production in south Africa: Impacts and adaptation options. Journal of Agricultural Science. 4(10):41-69.

Mohammadi Yeganeh B, Rezaei Pejand H, Cheraghi Ch (2012). Drought effects on the economics of rural areas of Abarkouh (2006-1996). Regional Planning Quarterly. 2(6):57-68. [Persian]

Naveen P, Singh Cynthia B, Byjesh K (2014). Vulnerability and policy relevance to drought in the semi-arid tropics of 